\title{
Sleep, sleep-disordered breathing and metabolic consequences
}

\author{
P. Lévy*, M.R. Bonsignore ${ }^{\#, \oplus}$ and J. Eckel ${ }^{+}$
}

ABSTRACT: Sleep profoundly affects metabolic pathways. In healthy subjects, experimental sleep restriction caused insulin resistance (IR) and increased evening cortisol and sympathetic activation. Increased obesity in subjects reporting short sleep duration leads to speculation that, during recent decades, decreased sleeping time in the general population may have contributed to the increasing prevalence of obesity. Causal inference is difficult due to lack of control for confounders and inconsistent evidence of temporal sequence.

In the general population, obstructive sleep apnoea (OSA) is associated with glucose intolerance. OSA severity is also associated with the degree of IR. However, OSA at baseline does not seem to significantly predict the development of diabetes. Prevalence of the metabolic syndrome is higher in patients with OSA than in obese subjects without OSA. Treatment with continuous positive airway pressure seems to improve glucose metabolism both in diabetic and nondiabetic OSA but mainly in nonobese subjects.

The relative role of obesity and OSA in the pathogenesis of metabolic alterations is still unclear and is intensively studied in clinical and experimental models. In the intermittent hypoxia model in rodents, strong interactions are likely to occur between haemodynamic alterations, systemic inflammation and metabolic changes, modulated by genetic background. Molecular and cellular mechanisms are currently being investigated.

KEYWORDS: Diabetes, insulin resistance, intermittent hypoxia, obesity, sleep, sleep apnoea

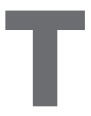

here is compelling evidence that sleep apnoea represents a major cardiovascular risk [1-8]. Many studies have reported an independent association of obstructive sleep apnoea (OSA) with several components of the metabolic syndrome (MetS), particularly insulin resistance (IR) and abnormal lipid metabolism [9, 10]. This association may further increase cardiovascular risk [11], since the MetS is recognised to be a risk factor for cardiovascular morbidity and mortality $[12,13]$.
Rapidly accumulating data from both epidemiological and clinical studies [14, 15] suggest that OSA is independently associated with alterations in glucose metabolism and places patients at an increased risk of the development of type 2 diabetes. Recent reports have indicated that many patients with type 2 diabetes have OSA [15]. Even though there is emerging evidence that the relationship between type 2 diabetes and OSA is at least partially independent of adiposity $[16,17]$, there are several important limitations in
AFFILIATIONS

*INSERM ERI 17, HP2 laboratory,

Joseph Fourier University and Sleep Laboratory, EFCR, Pôle Rééducation et Physiologie, CHU Grenoble,

Grenoble, France,

"Dept of Medicine, Pneumology,

Physiology and Nutrition

(DIMPEFINU), University of Palermo,

"Institute of Biomedicine and

Molecular Immunology (IBIM),

National Research Council (CNR),

Palermo, Italy, and

${ }^{+}$German Diabetes Center,

Düsseldorf, Germany.

CORRESPONDENCE

P. Lévy

EFCR

Pôle Rééducation et Physiologie

CHU Grenoble

BP 217, 38043 Cedex

France

E-mail: PLevy@chu-grenoble.fr

Received:

Nov 052008

Accepted after revision:

Feb 252009
Previous articles in this series: No. 1: MacLeod AK, Liewald DCM, McGilchrist MM, et al. Some principles and practices of genetic biobanking studies. Eur Respir J 2009; 33: 419-425. No. 2: Riha RL, Gislasson T, Diefenbach K. The phenotype and genotype of adult obstructive sleep apnoea/hypopnoea syndrome. Eur Respir J 2009; 33: 646-655. No. 3: Jennum P, Riha RL. Epidemiology of sleep apnoea/hypopnoea syndrome and sleep-disordered breathing. Eur Respir J 2009; 33: 907-914. No. 4: Garvey JF, Taylor CT, McNicholas WT. Cardiovascular disease in obstructive sleep apnoea syndrome: the role of intermittent hypoxia and inflammation. Eur Respir J 2009; 33: 1195-1205. No. 5: Lavie L, Lavie P. Molecular mechanisms of cardiovascular disease in OSAHS: the oxidative stress link. Eur Respir J 2009; 33: 1467-1484.

Earn CME accreditation by answering questions about this article. You will find these at the back of the printed copy of this issue or online at www.erj.ersjournals.com/current.dtl 
the published literature that do not allow causality to be established, i.e. cross-sectional studies, use of snoring as a surrogate marker of OSA, and various techniques for the assessments of glucose metabolism and type 2 diabetes. Recent state-of-the art reviews have highlighted these limitations and emphasised the need for further clinical research in this direction $[14,15]$.

In this article, we will review the physiological effects of sleep on glucose metabolism and the possible role of sleep disruption on the pathogenesis of metabolic abnormalities, the clinical evidence linking sleep disordered breathing (SDB) and impairment of glucose metabolism, the current evidence regarding the impact of continuous positive airway pressure (CPAP) treatment on glucose and insulin control, and the major role of adipose tissue and visceral obesity. We will further discuss the possible mechanisms by which OSA may contribute to metabolic dysregulation in light of the published evidence in humans and animal models, i.e. increased sympathetic activity, sleep fragmentation and intermittent hypoxia. This article will also refer to a European Respiratory Society Research Seminar held in Dusseldorf (Germany) from November 30-December 1, 2007 in conjunction with two EU COST (Cooperation in the field of Scientific and Technical Research) Actions on "Cardiovascular risk in OSAS" (B26) and "Adipose tissue and the metabolic syndrome" (BM0602).

\section{PHYSIOLOGICAL AND CLINICAL DATA Sleep and metabolism}

OSA may affect metabolism indirectly, by decreasing the amount and/or quality of sleep. Sleep loss profoundly affects metabolic pathways [18]. In healthy subjects, experimental sleep restriction caused IR, together with increased evening cortisol and sympathetic activation [19]. Sleep restriction was also shown to be associated with reduced leptin and increased ghrelin plasma concentrations and increased appetite [20]. Modest acute sleep loss, such as selective slow-wave sleep deprivation, may alter glucose tolerance in normal subjects [21]. In general population cohorts, short sleep duration was associated with altered plasma levels of leptin [22, 23] and ghrelin [22] and increased body mass index (BMI) [22, 23]. In young adults, a prospective study found a significant risk of obesity in subjects reporting short sleep duration [24], leading to speculation that decreased sleeping time over the recent decades may have contributed to the increasing prevalence of obesity in the general population. In addition, in general population cohorts, difficulties falling asleep, difficulties in sleep maintenance and reduction in sleep duration have been found to be associated with an increased incidence of diabetes in males $[25,26]$.

The causal relationship between sleep duration and obesity is far from being proven [27-30], as shown by recent critical reviews or meta-analyses of published data in this field [27, 31, 32]. Although cross-sectional studies from around the world show a consistent increased risk of obesity among short sleepers in children and adults [32], prospective data seem to fail to show this [33]. Causal inference is difficult due to lack of control for important confounders and inconsistent evidence of temporal sequence in prospective studies [27, 32]. Moreover, effect size and importance of sleep duration in comparison to other risk factors for obesity have been recently challenged [27, $34,35]$. However, causality is often difficult to establish in epidemiology owing to biological complexity and multiple interactions [36]. Moreover, a modest effect size, such as the average decrease in BMI by 0.35 units associated with one extra hour of sleep in the general population [32], may be unimportant on an individual basis but of major significance in public health [36]. From the available relative risk ratios and short sleep prevalence, YouNG [36] calculated that $5-13 \%$ of the total proportion of obesity in children and $3-5 \%$ in adults could be attributable to short sleep.

The mechanisms that are possibly involved are of interest. Sleep deprivation has been found to induce a pro-inflammatory state, with increased release of interleukin (IL)- 6 [37, 38] and production of IL- 6 and tumour necrosis factor (TNF)- $\alpha$ by circulating monocytes [39]. Nuclear factor (NF)-кB activation has been identified as a molecular pathway by which sleep restriction may influence leukocyte inflammatory gene expression and the risk of inflammation-related disease [40]. The proinflammatory effects of sleep restriction may, at least partly, be mediated by stress activation, i.e. sympathetic and/or cortisol activation [41-43]. In addition, the group of KNUTSON and VAN CAUTER [44] speculated that the adverse impact of sleep deprivation on appetite regulation is likely to be driven by increased activity in neuronal populations expressing the excitatory peptides orexins, which promote both waking and feeding [44-46].

In summary, sleep loss could affect metabolism via several mechanisms, but it is difficult to apply the currently available data to OSA. There are no studies specifically addressing the effects of sleep fragmentation (such as in OSA) on metabolism, as recently stated [47].

\section{Association between sleep apnoea, glucose intolerance and diabetes}

Early studies indicated a possible causal association between the presence of OSA and development of type 2 diabetes. However, most studies exhibited significant limitations including small sample size, highly selected populations, inadequate adjustment for confounders and use of surrogate markers of OSA [15]. Methods have also been highly variable among studies. Table 1 summarises current definitions used in clinical studies on glucose metabolism and the MetS [48-50].

Table 2 summarises the available epidemiological studies on the association of SDB with IR and diabetes [16, 51-62]. In general population studies $[25,63]$, snoring was shown to be a risk factor for the development of diabetes over $10 \mathrm{yrs}$ independent of confounding factors. Importantly, two population cross-sectional studies including only lean subjects (BMI $<25 \mathrm{~kg} \cdot \mathrm{m}^{-2}$ ) found an independent association between frequent snoring and reduced glucose tolerance [56, 62]. Several other sleep anomalies have also been related to type 2 diabetes [25, 26, 63]. The relationship between self-reported sleep complaints and risk of diabetes may be less pronounced in females [63] than in males [25]. The Sleep Heart Health Study [16] (performed in 2,656 individuals) showed that sleeprelated hypoxaemia was associated with glucose intolerance independently of age, sex, BMI and waist circumference. OSA severity was also associated with the degree of IR after 


\section{TABLE 1 Current definitions used in clinical studies}

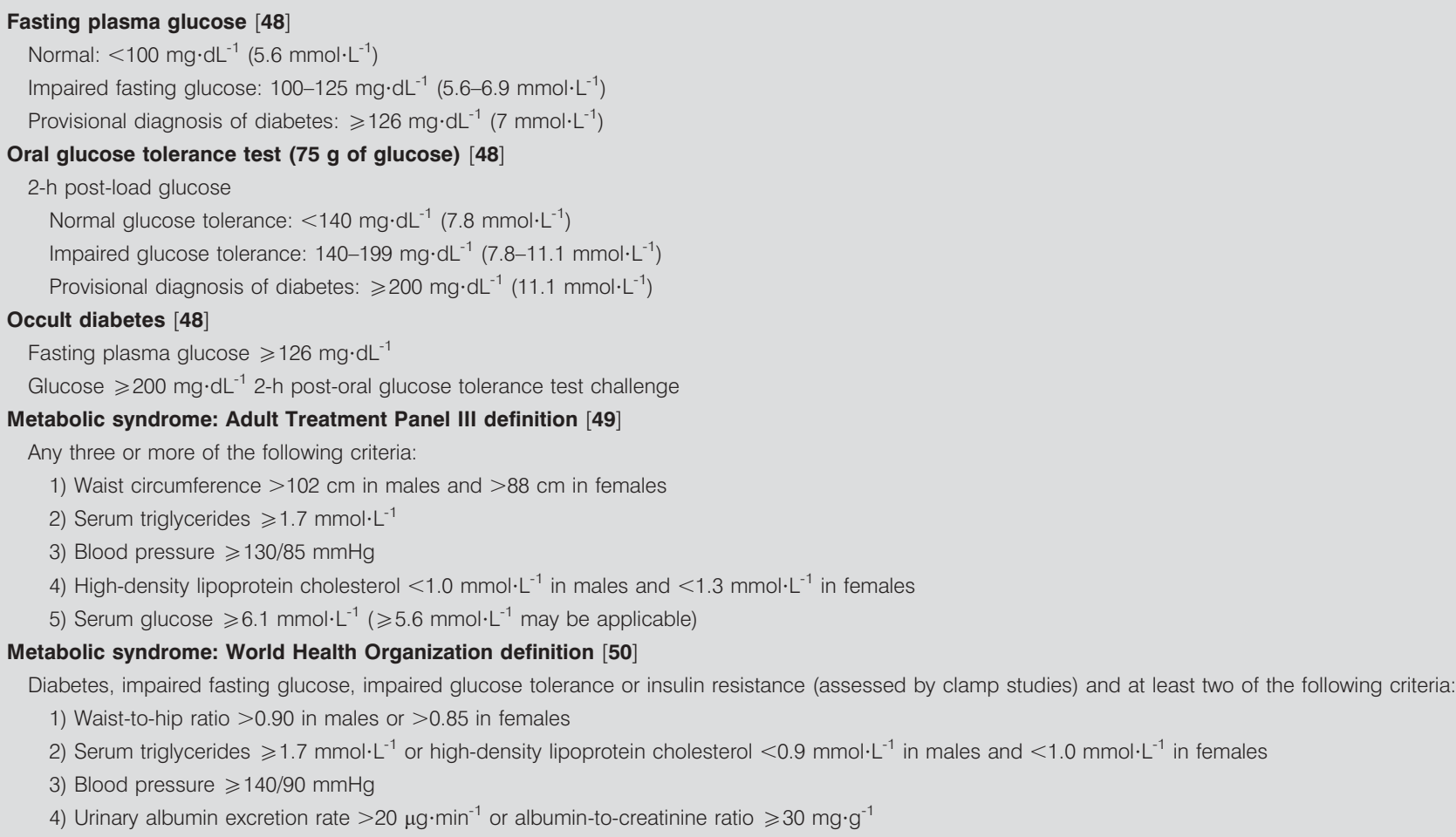

adjustment for obesity. More recently, these data have been confirmed in the same cohort, and the association between SDB and impaired glucose metabolism was found to be similar in normal-weight and overweight subjects [61]. The Wisconsin Sleep Study $(n=1,387)$ demonstrated a significant crosssectional association between OSA and type 2 diabetes for all degrees of OSA, which persisted for moderate-to-severe OSA after adjustment for obesity (odds ratio 2.3) [56]. However, although the longitudinal data showed that OSA at baseline predicted the development of diabetes over 4 yrs, significance disappeared after adjusting for obesity [56]. Finally, OSA was recently found to be independently associated with decreased insulin sensitivity in a population-based sample of females investigated with full-polysomnogram (PSG) and insulin sensitivity index (ISI) calculated from the results of an oral glucose tolerance test [62].

Similar data have been obtained in samples of OSA patients (tables 3 and 4) [64-80], with a large prevalence of positive [63, 64-79] rather than negative [78-80] studies. In clinical populations, OSA patients characterised by full-PSG were significantly more likely to have impaired glucose tolerance (IGT) and diabetes than subjects free of OSA syndrome (OSAS) [71]. The relationship between SDB and impaired glucose-insulin metabolism was independent of obesity and age [71]. A number of reports found increased IR and IGT in OSAS patients, independent of body weight [68-70, 75], and a worsening of IR with increasing apnoea/hypopnoea index (AHI) [54]. However, other studies failed to demonstrate an independent effect of $\mathrm{AHI}$ owing to the major impact of obesity $[64,65,80]$. Excessive daytime sleepiness (EDS) may also be of importance, as underlined by the recent findings that hyperglycaemia and IR only occurred in OSA patients presenting with EDS [77].

It may be concluded, in agreement with TASALI and IP [9], that despite the abundance of cross-sectional evidence for the link between OSA and abnormal glucose control, further welldesigned longitudinal and interventional studies are clearly needed to address the direction of causality.

\section{OSA and the metabolic syndrome}

According to clinical and epidemiological studies, the cluster of risk factors known as the MetS is associated with increased risk for diabetes, cardiovascular events and mortality in the general population [12]. Although the definition of the MetS is still under debate [81-83], IR is considered as the major metabolic abnormality, and is usually associated with an increased amount of visceral (dysfunctional) fat [84]. The World Health Organization definition of the MetS is based on the direct measurement of IR (table 1) [50]. Another definition (National Cholesterol Education Program-Adult Treatment Panel (ATP) III) is based on simple clinical findings (abdominal obesity, dyslipidaemia, hypertension and increased plasma glucose), and is easily applicable as it does not require tests to be performed in a specialised environment (table 1) [49]. Finally, the definition proposed by the International Diabetes Federation shares many features with the ATP III definition, but defines the cut-offs for waist circumference according to ethnicity [85], thus accounting for differences in body habitus between Caucasian and Asian populations. All these definitions should be considered as "in progress" and subject to 
TABLE 2 Epidemiological studies on insulin resistance (IR) and metabolic syndrome (MetS) in sleep disordered breathing (SDB)

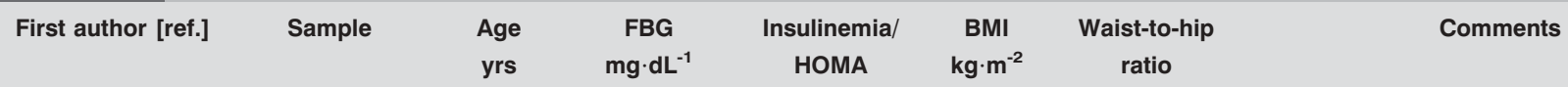

\begin{tabular}{|c|c|c|c|c|c|c|c|}
\hline \multirow[t]{3}{*}{ GRUnSteIn [51] } & $\begin{array}{l}\text { Suspected OSA } \\
\qquad(\mathrm{n}=864) \text { : }\end{array}$ & & & & & & \multirow[t]{3}{*}{$\begin{array}{l}\text { Cross-sectional study. Higher FBG, SBP and } \\
\text { DBP in obese subjects at high risk for OSAS }\end{array}$} \\
\hline & Low risk $43 \%$ & & & & & & \\
\hline & High risk $57 \%$ & & & & & & \\
\hline \multirow[t]{2}{*}{ ELMASRY [52] } & $\begin{array}{l}\text { General population } \\
(n=2668 \text { males }) \text { : }\end{array}$ & & & & & & \multirow{2}{*}{$\begin{array}{l}\text { Longitudinal study (10-yr follow-up). Incidence } \\
\text { of diabetes mostly explained by obesity, but } \\
\text { snoring seems to cause additional risk }\end{array}$} \\
\hline & Snorers (14.7\%) & 47 & & & 25.5 & & \\
\hline \multirow{3}{*}{ ELMASRY [53] } & Normal FBG $(n=83)$ & $61 \pm 10$ & $86 \pm 7$ & $10 \pm 6$ & 27 & 1 & \multirow{3}{*}{$\begin{array}{l}\text { Cross-sectional study. Mean } A H I=10 \text {. } \\
\text { Obesity and OSA may cause diabetes; OSA } \\
\text { could affect FBG and plasma insulin } \\
\text { independent of obesity }\end{array}$} \\
\hline & IGT $(n=8)$ & $55 \pm 8$ & $102 \pm 4$ & $12 \pm 7$ & 30 & 0.99 & \\
\hline & Diabetes $(n=25)$ & $61 \pm 8$ & $134 \pm 41$ & $16 \pm 7$ & 29 & 1.02 & \\
\hline Punjabi [54] & $\begin{array}{l}150 \text { males from the } \\
\text { general population: }\end{array}$ & & & HOMA & & & $\begin{array}{l}\text { Cross-sectional study. AHI correlated with } \\
\text { BMI but not with waist-to-hip ratio or body } \\
\text { fat (\%). IGT and IR associated with OSA } \\
\text { severity independent of obesity; metabolic } \\
\text { alterations appear before OSA symptoms }\end{array}$ \\
\hline \multirow[t]{4}{*}{ AL-Delaimy [55] } & $\begin{array}{l}\text { Nurses' Health Study } \\
\qquad(\mathrm{n}=69852) \text { : }\end{array}$ & & & & & & \multirow{4}{*}{$\begin{array}{l}\text { Longitudinal study (10-yr follow-up). Snoring } \\
\text { associated with high risk for diabetes, } \\
\text { independent of degree of obesity }\end{array}$} \\
\hline & Nonsnorers $26 \%$ & 50 & & & 24 & 0.77 & \\
\hline & $\begin{array}{l}\text { Occasional snorers } \\
65 \%\end{array}$ & 53 & & & 25 & 0.78 & \\
\hline & Habitual snorers 9\% & 53 & & & 28 & 0.81 & \\
\hline PunJabi [16] & $\begin{array}{l}\text { Sleep Heart Health } \\
\text { Study: }(n=2656)\end{array}$ & 68 & & & 27.4 & & $\begin{array}{l}\text { Cross-sectional study. FBG and IGT } \\
\text { associated with OSA; hypoxaemia during } \\
\text { sleep rather than AHI predicted IGT }\end{array}$ \\
\hline \multirow[t]{2}{*}{ Reichmuth [56] } & General population & & & & & & \multirow{2}{*}{$\begin{array}{l}\text { Cross sectional and longitudinal study. } \\
\text { High prevalence of diabetes in subjects } \\
\text { with OSA, but causal relationship unclear } \\
\text { (significance lost after adjusting for } \\
\text { body habitus) }\end{array}$} \\
\hline & (Wisconsin Sleep & & & & & & \\
\hline \multirow{2}{*}{ SHIN [57] } & Nonsnorers $86 \%$ & 51 & 88.3 & 6.5 & 23 & & \multirow{2}{*}{$\begin{array}{l}\text { Trend to increased risk for IGT and IR in } \\
\text { snorers compared with nonsnorers }\end{array}$} \\
\hline & Snorers $14 \%$ & 51 & 88.6 & 6.4 & 24 & & \\
\hline \multirow[t]{3}{*}{ LAM [58] } & $\begin{array}{l}\text { General population } \\
(\mathrm{n}=1612 \text { question- } \\
\text { naires, } n=255 \text { PSG): }\end{array}$ & & & & & & \multirow[t]{3}{*}{$\begin{array}{l}\text { Cross-sectional study. OSA associated with } \\
\text { several components of the MetS including IR }\end{array}$} \\
\hline & Non-OSA $(n=160)$ & 42 & 91.3 & & 24 & & \\
\hline & OSA $(n=95)$ & 45 & 98.5 & & 27 & & \\
\hline \multirow[t]{4}{*}{ Joo [59] } & $\begin{array}{l}\text { General population } \\
\text { (Korean Health and } \\
\text { Genome Study, } \\
n=6981 \text { ): }\end{array}$ & & & & & & \multirow[t]{4}{*}{$\begin{array}{l}\text { Cross-sectional study. Snoring associated } \\
\text { with increased risk for elevated } \mathrm{HbA} 1 \mathrm{c} \text { in } \\
\text { males before age } 50 \mathrm{yrs} \text { and in } \\
\text { premenopausal females }\end{array}$} \\
\hline & $\begin{array}{c}\text { Nonsnorers }(n=1224 \\
\text { males } / n=1706 \\
\text { females) }\end{array}$ & $53 / 51$ & $87 / 86$ & $5.5 / 5.5^{\circ}$ & $23 / 23$ & & \\
\hline & $\begin{array}{l}\text { Simple snoring } \\
\text { ( } n=1622 \text { males/ } \\
n=1574 \text { females })\end{array}$ & $51 / 52$ & $89 / 86$ & $5.6 / 5.6^{\bullet}$ & $24 / 24$ & & \\
\hline & $\begin{array}{l}\text { Habitual snoring } \\
\text { ( } \mathrm{n}=516 \text { males/ } \\
\mathrm{n}=339 \text { females })\end{array}$ & $51 / 56$ & $89 / 87$ & $5.6 / 5.7^{\bullet}$ & $24 / 24$ & & \\
\hline
\end{tabular}




\section{TABLE 2 Continued}

\begin{tabular}{|c|c|c|c|c|c|c|c|}
\hline First author [ref.] & Sample & $\begin{array}{l}\text { Age } \\
\text { yrs }\end{array}$ & $\begin{array}{c}\mathrm{FBG} \\
\mathrm{mg} \cdot \mathrm{dL}^{-1}\end{array}$ & $\begin{array}{l}\text { Insulinemia/ } \\
\text { HOMA }\end{array}$ & $\begin{array}{c}\mathrm{BMI} \\
\mathrm{kg} \cdot \mathrm{m}^{-2}\end{array}$ & $\begin{array}{l}\text { Waist-to-hip } \\
\text { ratio }\end{array}$ & Comments \\
\hline \multirow[t]{2}{*}{ ONAT [60] } & $\begin{array}{l}\text { General population } \\
\qquad(n=1946):\end{array}$ & & & $\begin{array}{l}\text { MetS +ve simi- } \\
\text { larly distributed } \\
\text { among OSA +ve } \\
\text { and OSA -ve } \\
\text { males } \\
\text { increased preva- } \\
\text { lence of MetS in } \\
\text { OSA +ve than } \\
\text { OSA -ve females }\end{array}$ & & & $\begin{array}{l}\text { Cross-sectional study. MetS in males with } \\
\text { OSA explained by abdominal obesity, IR not } \\
\text { significant. MetS in females with OSA } \\
\text { associated with smoking and CHD }\end{array}$ \\
\hline & $\begin{array}{l}\text { Males }(n=944) \\
\text { Females }(n=102)\end{array}$ & 54 & & & & & \\
\hline \multirow[t]{3}{*}{ SeICEAn [61] } & $\begin{array}{l}\text { Sleep Heart Health } \\
\text { Study }(n=2588) \text { : } \\
\text { Non-overweight con- }\end{array}$ & 66 & $\begin{array}{l}\text { FBG/OGTT } \\
\text { 93/116 }\end{array}$ & & 23 & & $\begin{array}{l}\text { Cross-sectional study. Magnitude of } \\
\text { association of SDB with alterations of } \\
\text { glucose metabolism similar in nonobese }\end{array}$ \\
\hline & $\begin{array}{l}\text { Overweight/obese } \\
\text { controls }(n=873)\end{array}$ & 66 & $96 / 128$ & & 28 & & \\
\hline & $\begin{array}{l}\text { Overweight/obese } \\
\text { OSA }(n=1036)\end{array}$ & 68 & $100 / 136$ & & 30 & & \\
\hline \multirow[t]{2}{*}{$\begin{array}{l}\text { THEORELL- } \\
\text { HAGLOW [62] }\end{array}$} & $\begin{array}{c}\text { Females from } \\
\text { Uppsala (Sweden) } \\
\text { general population } \\
\text { ( } \mathrm{n}=7051 \text { question- } \\
\text { naires, } \mathrm{n}=400 \mathrm{PSG} \text { ): }\end{array}$ & & & & & & $\begin{array}{l}\text { OSA independently associated with } \\
\text { decreased insulin sensitivity in females }\end{array}$ \\
\hline & Controls $(n=134)$ & 43 & $5.2 \mathrm{mmol} \cdot \mathrm{L}^{-1}$ & 6.4 & 25 & 0.83 & \\
\hline
\end{tabular}

Data are presented as mean $\pm \mathrm{SD}$, unless otherwise stated. FBG: fasting blood glucose; HOMA: homeostasis model assessment; BMI: body mass index; OSA obstructive sleep apnoea; IGT: impaired glucose tolerance; AHI: apnoea/hypopnoea index; PSG: polysomnogram; OGTT: oral glucose tolerance test; SBP: systolic blood pressure; DBP: diastolic blood pressure; OSAS: OSA syndrome; Hb: haemoglobinCHD: coronary heart disease; +ve: positive; -ve: negative. ${ }^{\#}$ : diabetes (\%); ๑ HbA1c (\% + subjects).

change based on the evidence provided by current and future studies.

The MetS can be explained by viewing abdominal adipose tissue as an endocrine organ (see below), releasing into the circulation excess harmful free fatty acids (FFA), angiotensin II and adipokines. Increased blood FFA inhibits the uptake of glucose by muscle. Because excess FFA and angiotensin II damage the pancreas, insulin release is not sufficient to counteract hyperglyacemia, resulting in IR [86]. The most prevalent form of this group of metabolic abnormalities linked to IR is found in patients with abdominal obesity, especially with an excess of intra-abdominal or visceral adipose tissue [87]. It has been suggested that visceral obesity may represent a clinical intermediate phenotype, reflecting the relative inability of subcutaneous adipose tissue to clear and store extra energy resulting from dietary triglycerides, thus leading to fat deposition in visceral adipose depots, skeletal muscle, liver, heart, etc. Thus, visceral obesity may be both a marker of a dysmetabolic state and a cause of the MetS [87].
MetS is often found in OSAS patients (table 5) $[10,58,65,74$, $75,88-92]$. However, the relative role played by OSA and obesity in the pathogenesis of MetS remains uncertain. Prevalence of the MetS is higher in patients with OSAS than in the European general population $(15-20 \%)$ or in obese subjects without OSAS [81]. In subjects with SDB, prevalence rates ranged from $19 \%$ in Korean snorers [57] to $87 \%$ in OSA patients from the UK [10]. The risk of developing the MetS increased with severity of SDB in Western as well as Eastern populations $[17,58,69,73,88-91,93]$. The studies published to date agree on the estimate of a five-fold (or higher) risk of MetS in OSAS patients compared with controls.

Most studies found a significant association between MetS and AHI, while the association with intermittent hypoxaemia was weak or absent. This result is at variance with the data obtained in animal models, which suggest a role of intermittent hypoxaemia in metabolic alterations (see below). In OSAS patients, apnoea or desaturation indexes showed stronger correlation with the amount of visceral fat than with 


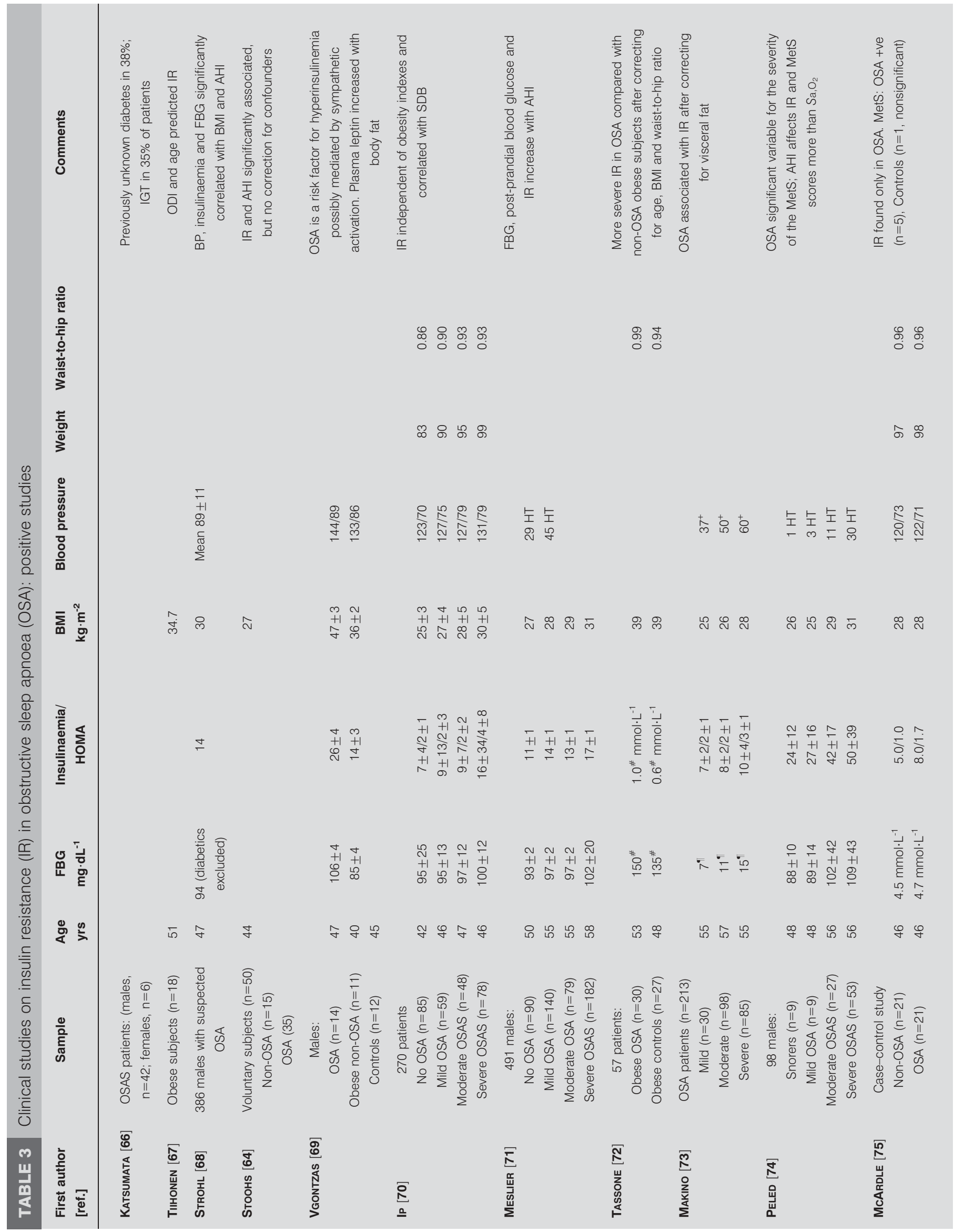




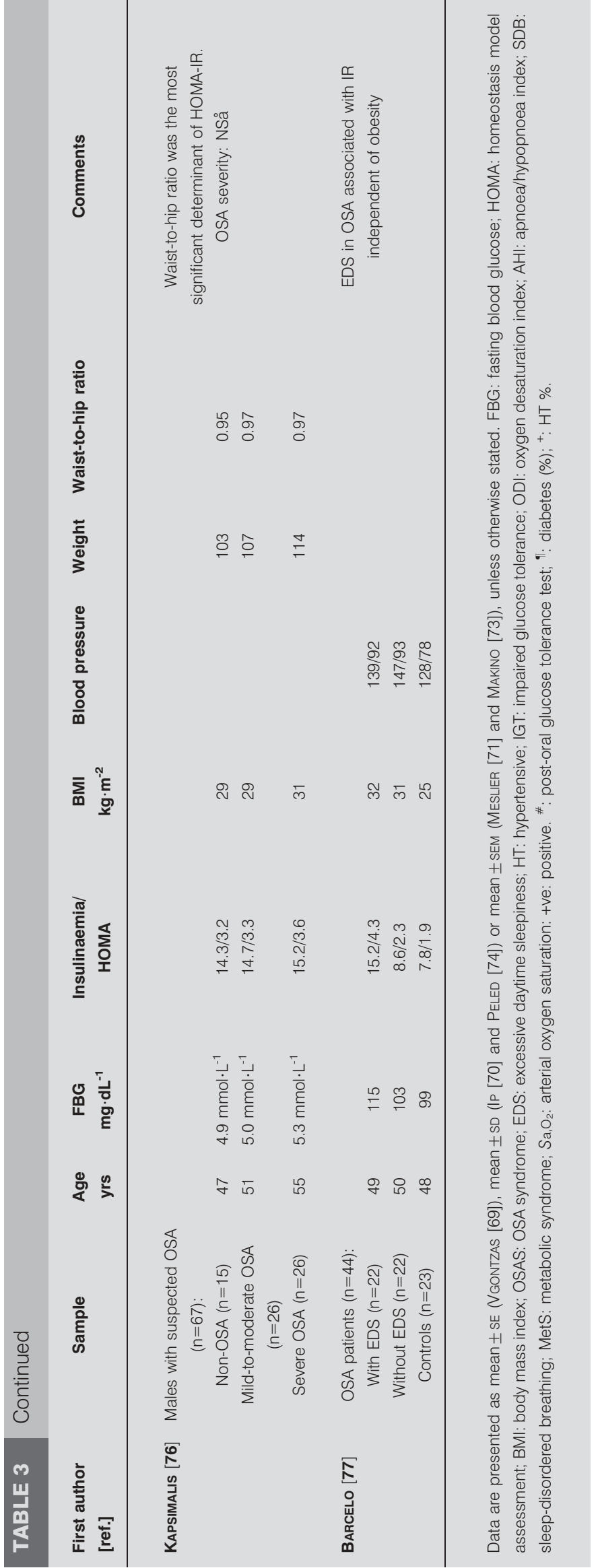

global obesity indexes, such as BMI [69], leading some authors to propose that OSAS should be considered as a component of the MetS [94]. However, the pathogenic mechanisms possibly leading from metabolic alterations to OSAS are still unclear. This is also illustrated by the fact that not all OSAS patients are obese, and not all obese subjects develop OSAS. Further studies with careful assessment of the amount and distribution of body fat are needed to better understand the pathophysiology of adipose tissue and its interaction with OSAS, taking into account the current progress in basic and clinical research on obesity.

\section{Effects of OSA treatment}

The effects of CPAP treatment on glucose metabolism have been evaluated in both nondiabetic and diabetic patients, as summarised in table $6[78,93,95-109]$, and may provide some clues as to the relative role of OSA and obesity in the pathogenesis of metabolic alterations. Until 2003, there were very few clear results owing to methodological issues and various confounders [92]. In 2004, HARSCH et al. [99] reported that CPAP treatment for 2 days rapidly improved the ISI in nondiabetic patients and that the positive effects of CPAP persisted after 3 months of treatment. Conversely, ISI improved only slightly and after prolonged treatment in obese patients (BMI $>30 \mathrm{~kg} \cdot \mathrm{m}^{-2}$ ), suggesting that in the latter group insulin sensitivity is primarily determined by obesity and, to a lesser extent, by sleep apnoea [99]. In nondiabetic patients, increased blood glucose was found after 1 night of CPAP treatment, with a tendency to higher fasting insulin and resistance to insulin (i.e. homeostasis model assessment (HOMA)-IR) after CPAP [101]. Such an increase in blood glucose might be related to CPAP-associated increase in growth hormone [95, 97], leading to an increase in plasmatic FFA owing to growth hormone lipolytic effects and thus to reduced glucose utilisation by skeletal muscles.

CPAP treatment does not greatly affect the metabolic status of obese OSA patients. A randomised, placebo-controlled, blinded crossover trial comparing cardiovascular and metabolic outcomes after 6 weeks of therapeutic or sham CPAP reported no change in glucose, lipids, IR or the proportion of patients with MetS in obese males, while positive effects of treatment on blood pressure and EDS were clearly present in the therapeutic CPAP group [105]. Whether EDS is also a critical determinant of the response to CPAP treatment, as recently reported [77], needs further evaluation in randomised control trials of large samples.

The limited duration of randomised controlled studies in OSA patients could, at least partly, account for the nonsignificant effects of CPAP treatment on glucose metabolism found in most studies. An observational study in a highly selected sample of OSAS patients found improved insulin sensitivity in patients with good compliance to CPAP after $2.9 \mathrm{yrs}$ of treatment [108]. Similarly, the Swedish Obesity Study reported a three-fold incidence of diabetes and hypertriglyceridaemia in patients with witnessed apnoeas compared to subjects with no OSA at 2 yrs follow-up [110]. Two studies reported that visceral fat decreased after CPAP treatment $[103,111]$ while a more recent study [93] found no change in IR or visceral fat after CPAP for 3 months. Therefore, large longitudinal studies 


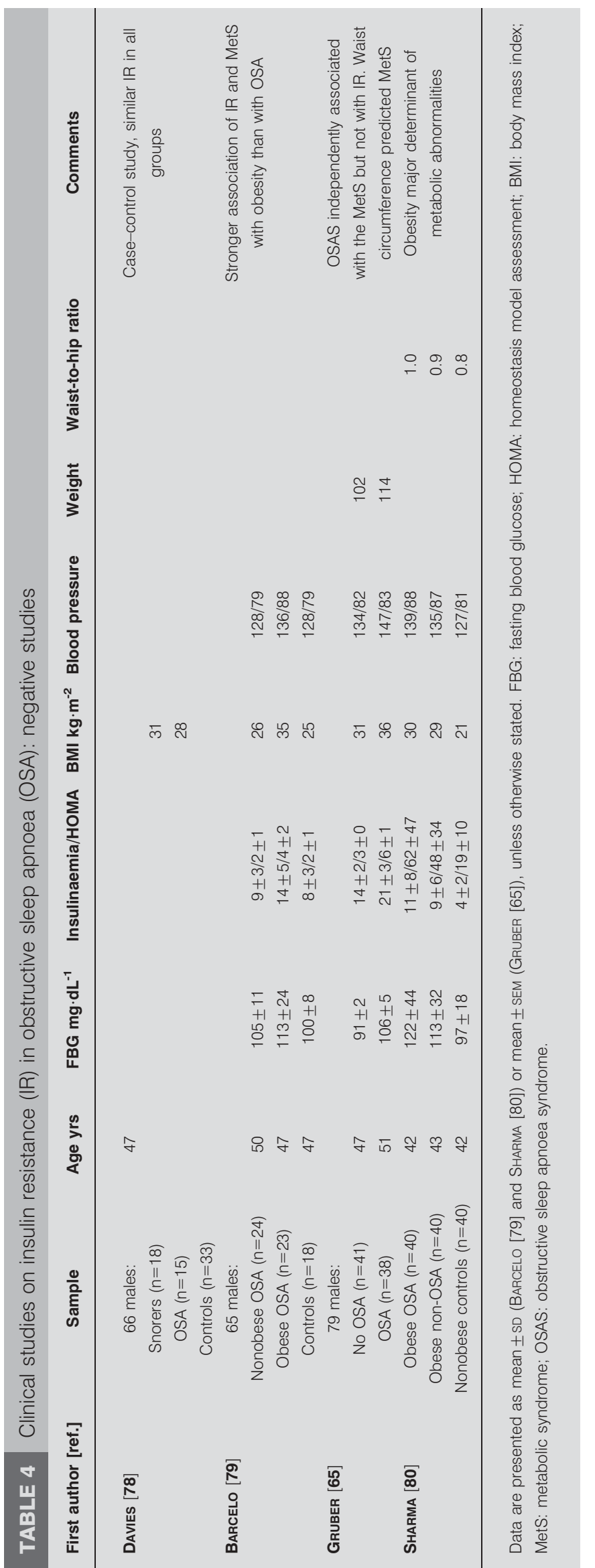

focusing on different aspects of this complex topic are needed to assess the potential long-term effect of OSA treatment.

In type 2 diabetic patients with OSAS, several studies have assessed the impact of CPAP treatment on glycaemic control. Recent observational studies using continuous glucose monitoring techniques have reported positive effects of CPAP on glycaemic control, already present during the first night of treatment, as variability of glycaemic values decreased compared with baseline conditions [107]. DAWSON [109] found decreased glucose levels and variability without significant changes in haemoglobin ( $\mathrm{Hb}) \mathrm{A} 1 \mathrm{c}$ levels. Conversely, BABU et al. [102] reported the results of 72-h continuous monitoring of interstitial glucose and measurements of $\mathrm{HbA} 1 \mathrm{c}$ levels in 25 patients before and after 3 months of CPAP. Post-prandial glucose values were significantly reduced $1 \mathrm{~h}$ after treatment, and $\mathrm{HbA} 1 \mathrm{c}$ level decreased in patients with abnormally high baseline $\mathrm{HbA1c}$ $(>7 \%)$. Furthermore, in subjects who used CPAP for $>4 \mathrm{~h} \cdot$ day $^{-1}$, the reduction in $\mathrm{HbA} 1 \mathrm{c}$ level was significantly correlated with CPAP use [102]. A retrospective study also confirmed a slight reduction in $\mathrm{HbA1c}$ in diabetic patients with OSA treated with CPAP [100]. However, obesity was likely to be a major confounding factor, since a randomised controlled trial comparing therapeutic $(n=20)$ or placebo CPAP $(n=22)$ for 3 months found no difference in terms of glycaemic control or IR in these patients [105]. In summary, a huge impact of obesity is also present in type 2 diabetic patients, which may offset the impact of CPAP $[112,113]$.

The effects of CPAP treatment on the MetS are controversial, as recently summarised in two reviews $[9,114]$. A recent observational study in patients with severe OSAS reported decreased blood pressure and plasma cholesterol and improved HOMA index after 8 weeks of CPAP treatment in patients with good compliance to therapy; the estimated effect of CPAP over 10 yrs was a decrease in cardiovascular risk from $18.8 \%$ to $13.9 \%$ [106]. However, a randomised controlled study in patients with moderate-to-severe OSAS showed that IR or other MetS variables were unaffected after 6 weeks of effective CPAP [104]. Moreover, some studies suggested positive effects on plasma lipids after CPAP in patients showing a good compliance to treatment [106, 115, 116], while other studies found no effect of OSA treatment on plasma cholesterol or triglycerides [93, 104].

Other markers of glucose metabolism have been assessed in OSA patients, such as insulin growth factor (IGF)-1 and adiponectin. A high IGF-1 concentration is predictive of decreased risk of type 2 diabetes and impaired glucose tolerance $[117,118]$, whereas low IGF-1 concentrations were found to be associated with increased risk of cardiovascular disease [119]. The complex interactions between IGF-1, its binding proteins and insulin sensitivity promote IGF-1 as an important regulator of glucose homeostasis. While fasting insulin and blood glucose are subject to short-term changes, IGF-1 is a more stable variable subject to long-term regulation. In a population-based cohort, IGF-1 significantly increased after CPAP treatment [117]. However, in OSA patients' improvement in IGF-1 after CPAP was reported to occur only in patients presenting with EDS [76]. Adiponectin is known to counteract the effects of IR [120], and the effects of OSA treatment on adiponectin have been assessed with controversial results. 


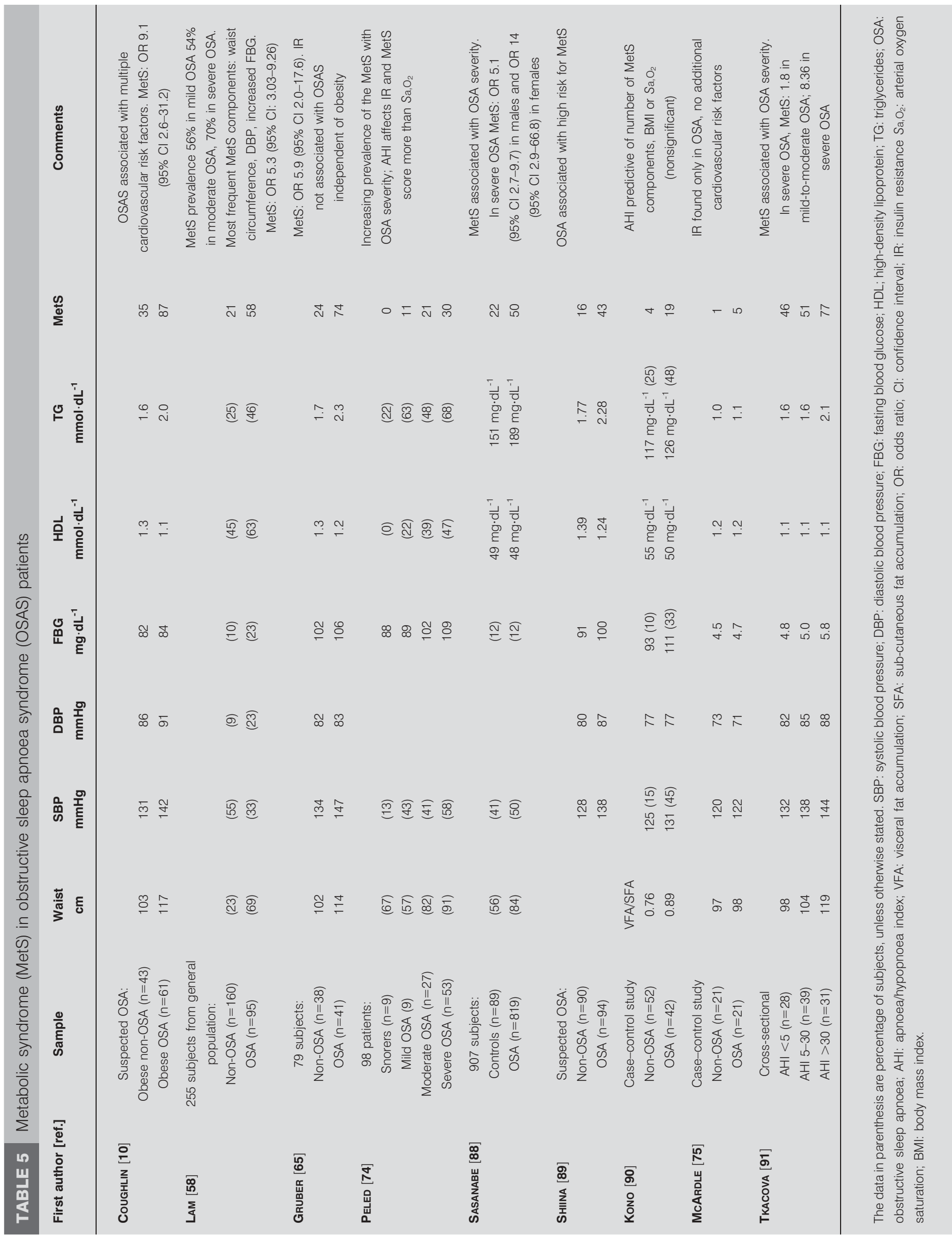


TABLE 6 Clinical studies on glycaemic control and insulin resistance (IR) in obstructive sleep apnoea syndrome (OSAS) patients before and after continuous positive airway pressure (CPAP) treatment

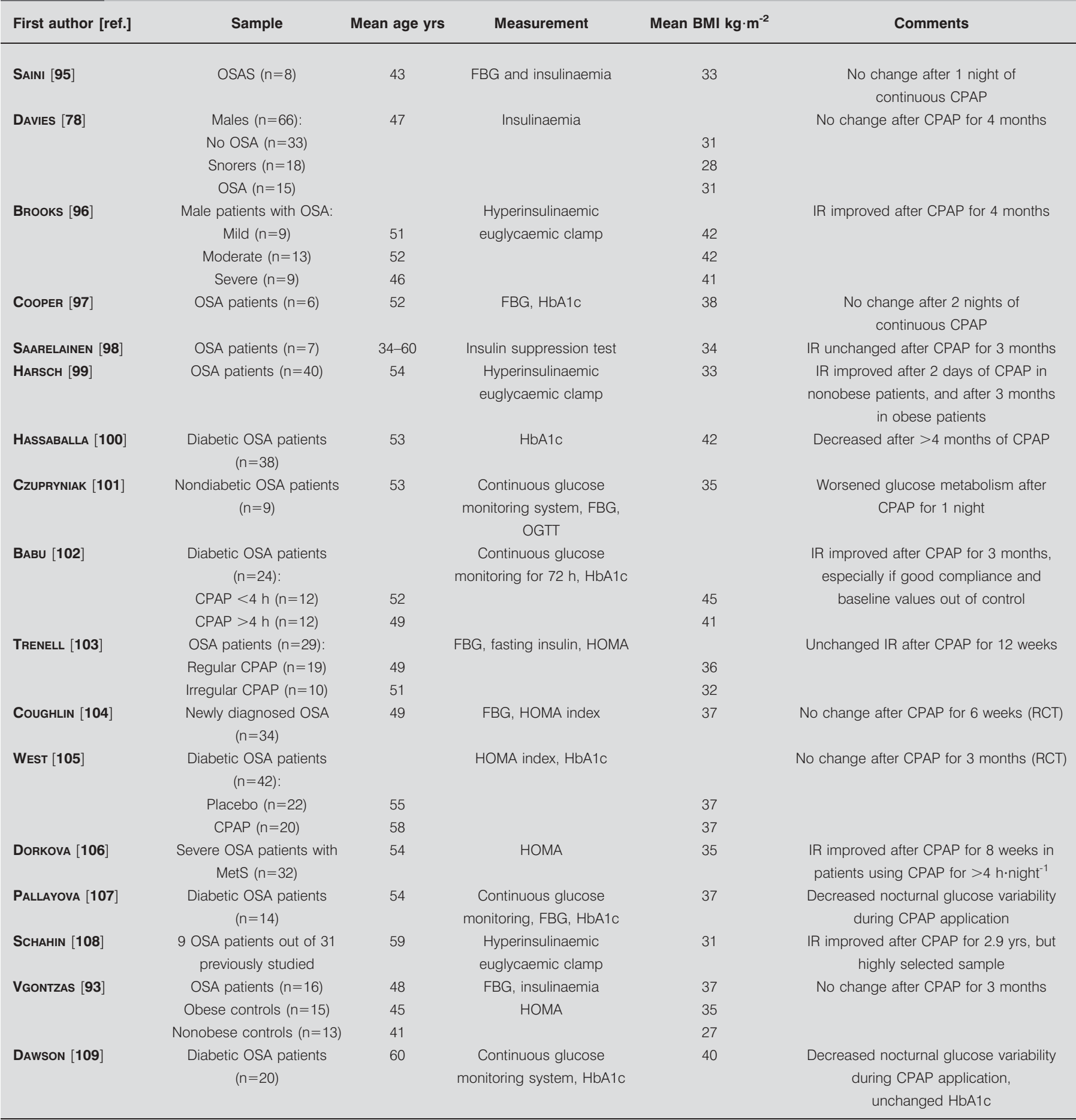

BMI: body mass index; OSA: obstructive sleep apnoea; MetS: metabolic syndrome; FBG: fasting blood glucose; Hb: haemoglobin; OGTT: oral glucose tolerance test; HOMA: homeostasis model assessment; RCT: randomised controlled trial.

Some studies found increased adiponectin after 1 night [121] or 2 weeks [122] of CPAP treatment, while other studies found no change in adiponectin levels after OSA treatment for 1 night [123] or 1-3 months [93, 124, 125].
It is possible that OSA treatment may positively affect only some MetS components, rather than affecting all of them [110, 115]. The available results need further confirmation. There is a strong need for controlled prospective studies, to evaluate 
whether some patient subgroups might especially benefit from the effects of CPAP treatment on metabolic variables [14].

\section{OSA and glucose metabolism in paediatrics}

Children and adolescents represent a very important clinical population since epidemic obesity in paediatrics is a major health concern $[125,126]$ and is associated with high MetS prevalence [127], although the real relevance of the MetS in adolescents is currently under discussion [128]. In addition, children classically represent a good clinical model for examining the relationship between SDB and glucose metabolism with limited coexistent comorbidity, even though differences between adult and paediatric OSA may have become smaller due to the current high prevalence of obesity at a young age [129]. The causal role of SDB in paediatric metabolic abnormalities is currently unclear, as indicated in a recent review [130].

In the general population, SDB in children seems to be associated with MetS [131]. In the Cleveland Cohort [131], after adjusting for age, race, sex and preterm status, children with SDB had a 6.49 increased odds of MetS compared with children without SDB [131]. Approximately $25 \%$ of the sample was overweight and $19 \%$ had MetS. In clinical samples of obese children, SDB was found to correlate with fasting insulin levels independent of BMI $[132,133]$. This has been challenged among children with suspected SDB, in whom IR and dyslipidaemia seem to be determined primarily by the degree of body adiposity rather than by the severity of SDB [134, 135]. In nonobese children, severity of SDB was not a significant predictor of fasting insulin or HOMA index values [136].

As for adipokine levels in children with SDB, obesity appeared as the primary determinant although SDB and associated hypoxaemia may contribute to elevated leptin levels [137]. In a recent study conducted in obese and nonobese children, GOZAL et al. [138] showed that SDB was associated with altered lipid homeostasis and systemic inflammation. In the presence of obesity, SDB also affected glucose metabolism through reduction in insulin sensitivity, independent of obesity [138]. Therefore, in obese children there could be an interaction between increased adiposity and SDB to promote and amplify IR.

Few data have been obtained in children on the effects of treatment for OSA on metabolic abnormalities. A small study reported a slight improvement in plasma high-density lipoprotein cholesterol after adenotonsillectomy, but no major changes in insulin level [135]. Leptin and sympathetic markers were found to be increased at baseline in children with SDB compared to simple snorers, and decreased after CPAP treatment for 3 months [139]. However, IR was unaffected by treatment [139]. Also, no change was shown in insulin level or HOMA index compared to baseline measurements in a sample of Greek children after adenotonsillectomy [140].

In summary, the field of SDB and its metabolic consequences together with its interaction with obesity is rapidly developing, but uncertainties remain significant as highlighted by recent reviews and editorials [141-143].

\section{MECHANISMS AND EXPERIMENTAL DATA Role of adipose tissue and visceral obesity}

White adipose tissue is considered to be a key endocrine and secretory organ that releases a large number of adipokines with a major link to inflammation and immunity. The paradigm shift in adipose tissue biology was initiated in 1994 by the discovery of leptin [144]. Subsequently, a growing number of proteins, peptides and other factors released from white adipocytes, collectively termed adipocytokines, have been described [145]. Most of these adipocytokines are linked to inflammation and their production is increased in obesity. To date, only adiponectin is known to exert anti-inflammatory and anti-diabetic activity, and is reduced in obesity and type 2 diabetes [146, 147].

Human obesity is characterised by increased rather than low leptin production. In OSAS patients, several studies reported increased leptin levels compared to weight-matched controls $[69,148-152]$, which correlated with OSA severity [148, 150, 151] and decreased after CPAP [111, 148, 153, 154]. Similar results were recently reported in paediatric OSA [139]. Therefore, OSA may exert an independent effect on leptin levels, causing leptin resistance, possibly through hypoxia, which acts by increasing leptin gene transcription [155].

Adipose tissue inflammation is thought to play a key role in the development of MetS, type 2 diabetes and cardiovascular disease [156]. In 2004, TRAYHURN and WOOD [157] suggested that adipose tissue inflammation may represent a specific response to relative hypoxia in clusters of adipocytes that become distant from the vasculature as cell size increases. It has since been demonstrated that hypoxia occurs in adipose tissue of obese mouse models and triggers expression of inflammatory adipokines [158].

Hypoxia-induced factor (HIF)-1 plays a key role in the response to hypoxia in most tissues. Transcription factors such as NF- $\mathrm{BB}$ and CREB are downstream targets of HIF-1. The number of hypoxia-sensitive genes is continuously growing, and to date $>70$ genes have been described as targets of HIF-1. These genes include proteins involved in angiogenesis, cell proliferation, apoptosis and energy metabolism [159]. Hypoxia may increase expression and secretion of a variety of inflammation-related adipocytokines such as IL-6, macrophage migration inhibitory factor and vascular endothelial growth factor. Therefore, hypoxia is likely to affect adipocyte function and promote adipose tissue inflammation. This may play a critical role in obesity-related disorders and may trigger the development of peripheral resistance to insulin and thus promote the development of type 2 diabetes and the MetS. The relationship between HIF-1 and inflammation has been discussed in detail in another article of this series [160].

Analysis of secretory products from primary human adipocytes revealed that these cells release classical adipocytokines such as TNF- $\alpha$, IL-6, leptin, and adiponectin, as well as newly discovered adipocytokines i.e. tissue inhibitor of metalloproteinases-1 and monocyte chemotactic protein (MCP)-1 [161]. MCP-1 was first described as a secretory product of monocytes and endothelial cells with a prominent role in arteriosclerosis but it is also associated with the obese state. MCP-1 exhibits IR-inducing capability in adipocytes and myocytes [162].

Increased expression and secretion of adipokines in obesity may be a marker of low-grade chronic inflammation in adipose tissue. Protein kinase $\mathrm{C}$ and IкB kinase (IKK) are two kinases known to 
be involved in the inflammatory processes underlying IR. IKK influences insulin sensitivity, especially in skeletal muscle, by inhibiting insulin signalling by insulin receptor substrate-1 phopshorylation on serine residues and by activating NF-кB. In turn, NF- $\mathrm{KB}$ regulates production of pro-inflammatory cytokines such as TNF- $\alpha$ and IL-6 [163], and generates both hepatic and systemic inflammation as well as IR [164].

In summary, the adipose tissue in obesity shows abnormal function and evidence of hypoxia and inflammation. This might be worsened by the occurrence of apnoeas during sleep, with further hypoxia and inflammation. The relative role of obesity and OSA in the pathogenesis of metabolic alterations is still unclear and is being intensively studied both in clinical and experimental models.

\section{OSA, oxidative stress, inflammation and adipose tissue}

OSA cardiovascular and metabolic consequences are now viewed as a component of a systemic disease resulting from oxidative stress [165], and systemic and vascular inflammation [166-172]. Inflammation appears to be mostly confined to the vascular compartment, while systemic inflammation is often absent or mild. This may account for the variable level of Creactive protein, which is often found not to be elevated in OSA patients without comorbidities [173, 174].

Obesity associated with OSA appears to be the strongest determinant of systemic inflammation [175]. Adipose tissue inflammation may play a critical role in OSA-associated morbidity [176], with peri-vascular adipose tissue especially contributing to the release of cytokines, TNF- $\alpha$, pro-atherogenic chemokines, and pro-angiogenic peptides [177, 178] (fig. 1). Whether these factors contribute directly to alterations in the function and structure of the vascular wall and the development of atherosclerosis and cardiovascular complications in OSA remains to be studied.

\section{Intermittent hypoxia}

Intermittent hypoxia $(\mathrm{IH})$ is considered the peculiar pathophysiological aspect of OSA and has been extensively studied in lean and obese rodent models. Recent reviews have

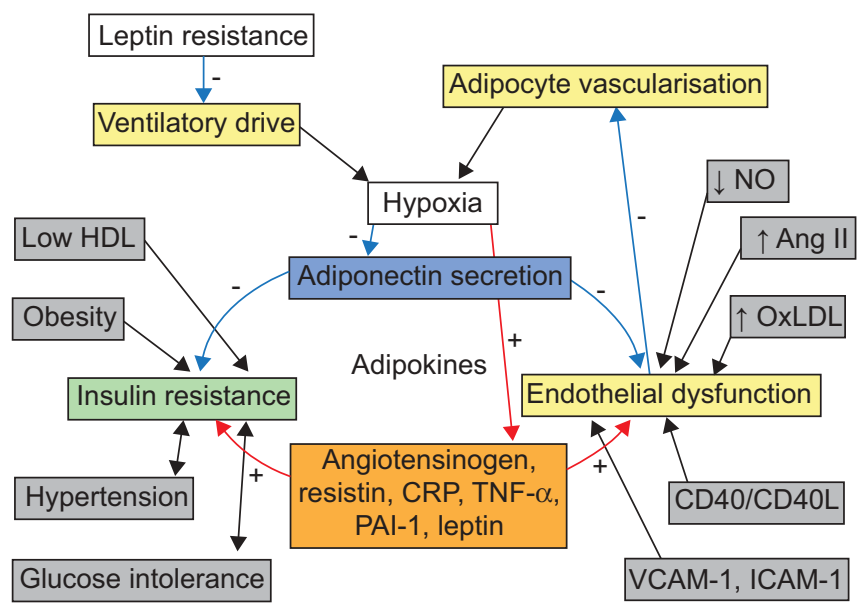

FIGURE 1. Effects of hypoxia on adipokines and their interactions with insulin metabolism and endothelial function. The main factors involved are leptin angiotensinogen (Ang), resistin, C-reactive protein (CRP), tumour necrosis factor (TNF)- $\alpha$ and plasminogen activator inhibitor (PAl)-1. Leptin promotes (red arrows) insulin resistance and endothelial dysfunction, whereas adiponectin is protective (blue arrows). Obesity, a state of leptin resistance and endothelial dysfunction, also exhibits hypoxia, which is known to activate (red arrow) promoting adipokines and inhibit (blue arrows) adiponectin production. In OSA, obesity and night-time hypoxia might act synergistically in producing inflammation at the systemic and vascular level, and in promoting metabolic and cardiovascular dysfunction. HDL: highdensity lipoprotein; OxLDL: oxidised low-density lipoprotein; CD40L: CD40 ligand; VCAM-1: vascular cell adhesion molecule-1; ICAM-1: intercellular adhesion molecule-1; +: activation/promotion; -: inhibition/protection. Modified from [178].

summarised experimental and clinical data linking $\mathrm{IH}$ to cardiovascular and metabolic alterations [178]. Metabolic and atherosclerotic changes have been shown in mice exposed to chronic IH [179-183].

In the chronic IH model (35 days) in mice, both systemic and localised inflammation of small and large arteries occurred, with evidence of peri-adventitial localisation of T-cells infiltration highly suggestive of a critical role of the peri-adventitial fat in the IH-related vascular inflammation (C. Arnaud,

\section{TABLE 7 Summary data on metabolic variables in studies on the effects of intermittent hypoxia (IH) in lean and obese mice}

\begin{tabular}{|c|c|c|c|c|c|c|}
\hline IH exposure & $\begin{array}{l}\text { Fasting blood } \\
\text { glucose }\end{array}$ & Fasting insulin & $\begin{array}{l}\text { Insulin sensitivity- } \\
\text { fasting (HOMA index) }\end{array}$ & $\begin{array}{l}\text { Glucose tolerance or euglycaemic } \\
\text { hyperinsulinaemic clamp }\end{array}$ & Plasma TG/TC/PL & $\begin{array}{c}\text { Liver content TG/TC/ } \\
\text { PL }\end{array}$ \\
\hline \multicolumn{7}{|l|}{ Lean mice } \\
\hline Short term & $\downarrow^{189}$ & $={ }^{189}$ & $\uparrow^{189}$ & $\uparrow^{189}$ & $\uparrow / \uparrow / \uparrow{ }^{179}$ & $\uparrow /=/={ }^{179}$ \\
\hline Long term & $\uparrow^{189}$ & $\downarrow^{188}$ & $\downarrow^{189}$ & & $\uparrow / \uparrow{ }^{192}$ & $\downarrow / \downarrow / \downarrow^{192}$ \\
\hline \multicolumn{7}{|l|}{$\mathrm{Ob} / \mathrm{Ob}$ mice } \\
\hline Long term & $={ }^{189}$ & $\uparrow \uparrow^{189}$ & $\downarrow \downarrow^{189}$ & $\downarrow \downarrow^{189}$ & $=/=/={ }^{189}$ & $\uparrow /=/ \uparrow 189$ \\
\hline \multicolumn{7}{|c|}{ High-fat fed mice } \\
\hline Long term & $\downarrow^{191}$ & $\downarrow^{191}$ & $={ }^{191}$ & & $=/=/ \mathrm{NA}^{191}$ & $=/ \uparrow / N A^{191}$ \\
\hline
\end{tabular}

The arrows indicate the direction of change (increase or decrease) of each parameter in mice exposed to $\mathrm{H}$. Numbers indicate reference. HOMA: homeostasis model assessment; TG: triglyceride; TC: total cholesterol; PL: phospholipids; Ob: genetically obese; NA: not available. $\uparrow$ : increase; $\downarrow$ : decrease; =: no change. ${ }^{\#}$ : glucose load by intraperitoneal glucose tolerance test or euglycaemic hyperinsulinaemic clamp. 
University of Grenoble, Grenoble, France; personal communication). Indeed, this does not rule out haemodynamic factors as, in another study in mice [180], platelet endothelial cell adhesion molecule-1, a marker of the endothelial cell, was decreased at both the heart and aorta level with a specific gradient, without loss of endothelial cells, possibly indicating a role for shear forces applied to the heart and aorta. Thus, vascular remodelling may result from either haemodynamic or inflammatory changes, or both. From these studies and others already published [166, 179, 183-185], strong interactions are likely to occur in response to chronic IH between haemodynamic alterations, systemic inflammation and metabolic changes, and modulated by genetic background [178, 182]. Inflammation may largely contribute to glucose homeostasis dysregulation.

Indeed, from a metabolic perspective, several pieces of evidence support a role for $\mathrm{IH}$ in the metabolic alterations seen in OSA. Exposure of lean mice (C57BL/6J) to $\mathrm{IH}$ for 5 days increased serum cholesterol and phospholipids levels, up-regulated triglycerides and phospholipid biosynthesis, and inhibited cholesterol uptake in the liver [179]. These effects may be mediated through HIF-1 activation for triglycerides and the post-transcriptional regulation of lipid biosynthesis (sterol regulatory element binding protein-1) but not for serum cholesterol levels [186].

IH may result in acute IR in otherwise lean, healthy animals, and the response is associated with decreased glucose utilisation of oxidative muscle fibres, independent of autonomic nervous system activation [185]. The magnitude of metabolic alterations may also depend on the severity of $\mathrm{IH}$ [184]. However, in contrast to the persistent effects of chronic $\mathrm{IH}$ on sympathetic activity and blood pressure, the effects of $\mathrm{IH}$ on glucose homeostasis appear to be limited to the periods of hypoxic exposure [187]. Moreover, combining IH exposure and glucose infusion amplified the alteration of blood glucose diurnal rhythm and led to high rates of apoptosis in $\beta$-cells [187]. The overall effects of $\mathrm{IH}$ on glucose homeostasis are summarised in table 7 [179, 185, 188-192], and appear highly complex, in part, because IH causes loss of weight in lean animals, which counteracts IR. However, these data support the findings in humans suggesting a synergistic effect of increased adiposity and SDB in promoting metabolic dysfunction. Finally, it should be reminded that sleep fragmentation and intermittent hypoxia may also interact in modulating glucose homeostasis in animal models as well as in OSA, but the effects of sleep fragmentation are extremely difficult to study, even in animal models [182].

A recent area of investigation is the potential role of $\mathrm{IH}$ as a "second hit" stimulus for the transition from hepatic steatosis to nonalcoholic steatohepatitis (NASH) [190-192]. Recent studies in mice exposed to chronic IH would support this possibility, since animals fed a regular diet developed mild liver injury, while animals fed a high-fat diet showed evidence of inflammation and fibrosis of the liver [191]. In both groups, there was evidence of hepatic oxidative stress. NASH is likely to be associated with hepatic IR and this may further contribute to glucose homeostasis dysregulation. This topic is still largely unexplored in the clinical context, since few studies to date have examined hepatic function in OSA patients. The available data suggest that at least some patients, both adults and children, may show evidence of hepatic dysfunction correlated with the severity of nocturnal IH [193, 194].

\section{CONCLUSIONS}

Alterations in sleep quantity or quality may affect glucose metabolism. However, although cross-sectional studies from around the world show a consistent increased risk of obesity among short sleepers in children and adults, large prospective studies are needed. In addition, in SDB, despite the abundance of cross-sectional evidence for the link between OSA and abnormal glucose control, further well-designed longitudinal and interventional studies are clearly needed to address the direction of causality. The available evidence also suggests that CPAP has little or no effect on the metabolic status of obese subjects, presumably owing to the major impact of visceral obesity. However, recent data obtained in diabetic OSA patients by using the technique of continuous monitoring suggest that CPAP treatment may improve glycaemic control. Thus, the synergistic negative effects of obesity and SDB represent a major research challenge, as shown by the complex picture emerging from studies in animal models. The interaction between hypoxia and metabolism possibly involves stress activation, oxygen radical production, and multiple cellular pathways (NF-кB, HIF and apoptosis) and cell types (inflammatory cells, vascular endothelium, adipocytes). There is a potential role for adipose tissue inflammation both regarding vascular remodelling and metabolic dysfunction. Clinical and translational research is urgently needed in this field.

\section{STATEMENT OF INTEREST}

None declared.

\section{REFERENCES}

1 Marin JM, Carrizo SJ, Vicente E, et al. Long-term cardiovascular outcomes in men with obstructive sleep apnoea-hypopnoea with or without treatment with continuous positive airway pressure: an observational study. Lancet 2005; 365: 1046-1053.

2 Arzt M, Young T, Finn L, et al. Association of sleep-disordered breathing and the occurrence of stroke. Am J Respir Crit Care Med 2005; 172: 1447-1451.

3 Peppard PE, Young T, Palta M, et al. Prospective study of the association between sleep-disordered breathing and hypertension. N Engl J Med 2000; 342: 1378-1384.

4 Doherty LS, Kiely JL, Swan V, et al. Long-term effects of nasal continuous positive airway pressure therapy on cardiovascular outcomes in sleep apnea syndrome. Chest 2005; 127: 2076-2084.

5 Young T, Finn L, Peppard PE, et al. Sleep disordered breathing and mortality: eighteen-year follow-up of the Wisconsin sleep cohort. Sleep 2008; 31: 1071-1078.

6 Marshall NS, Wong KK, Liu PY, et al. Sleep apnea as an independent risk factor for all-cause mortality: the Busselton Health Study. Sleep 2008; 31: 1079-1085.

7 Gami AS, Somers VK. Obstructive sleep apnoea, metabolic syndrome, and cardiovascular outcomes. Eur Heart J 2004; 25: 709-711.

8 McNicholas WT, Bonsignore MR. Sleep apnoea as an independent risk factor for cardiovascular disease: current evidence, basic mechanisms and research priorities. Eur Respir J 2007; 29: 156-178.

9 Tasali E, Ip MS. Obstructive sleep apnea and metabolic syndrome: alterations in glucose metabolism and inflammation. Proc Am Thorac Soc 2008; 5: 207-217. 
10 Coughlin SR, Mawdsley L, Mugarza JA, et al. Obstructive sleep apnoea is independently associated with an increased prevalence of metabolic syndrome. Eur Heart J 2004; 25: 735-741.

11 Bonsignore MR, Zito A. Metabolic effects of the obstructive sleep apnea syndrome and cardiovascular risk. Arch Physiol Biochem 2008; 114: 255-260.

12 Ford ES. Risks for all-cause mortality, cardiovascular disease, and diabetes associated with the metabolic syndrome: a summary of the evidence. Diabetes Care 2005; 28: 1769-1778.

13 Sundström J, Risérus U, Byberg L, et al. Clinical value of the metabolic syndrome for long term prediction of total and cardiovascular mortality: prospective, population based cohort study. BMJ 2006; 332: 878-882.

14 Tasali E, Mokhlesi B, Van Cauter E. Obstructive sleep apnea and type 2 diabetes: interacting epidemics. Chest 2008; 133: 496-506.

15 Shaw JE, Punjabi NM, Wilding JP, et al. Sleep-disordered breathing and type 2 diabetes: a report from the International Diabetes Federation Taskforce on Epidemiology and Prevention. Diabetes Res Clin Pract 2008; 81: 2-12.

16 Punjabi NM, Shahar E, Redline S, et al. Sleep-disordered breathing, glucose intolerance, and insulin resistance: the Sleep Heart Health Study. Am J Epidemiol 2004; 160: 521-530.

17 West SD, Nicoll DJ, Stradling JR. Prevalence of obstructive sleep apnoea in men with type 2 diabetes. Thorax 2006; 61: 945-950.

18 Knutson KL, Spiegel K, Penev P, et al. The metabolic consequences of sleep deprivation. Sleep Med Rev 2007; 11: 163-178.

19 Spiegel K, Leproult R, Van Cauter E. Impact of sleep debt on metabolic and endocrine function. Lancet 1999; 354: 1435-1439.

20 Spiegel K, Tasali E, Penev P, et al. Brief communication: sleep curtailment in healthy young men is associated with decreased leptin levels, elevated ghrelin levels, and increased hunger and appetite. Ann Intern Med 2004; 141: 846-850.

21 Tasali E, Leproult R, Ehrmann DA, et al. Slow-wave sleep and the risk of type 2 diabetes in humans. Proc Natl Acad Sci USA 2008; 105: 1044-1049.

22 Taheri S, Lin L, Austin D, et al. Short sleep duration is associated with reduced leptin, elevated ghrelin, and increased body mass index. PLoS Med 2004; 1: e62.

23 Chaput JP, Despres JP, Bouchard C, et al. Short sleep duration is associated with reduced leptin levels and increased adiposity: results from the Quebec family study. Obesity 2007; 15: 253-261.

24 Hasler G, Buysse DJ, Klaghofer R, et al. The association between short sleep duration and obesity in young adults: a 13-year prospective study. Sleep 2004; 27: 661-666.

25 Nilsson PM, Roost M, Engstrom G, et al. Incidence of diabetes in middle-aged men is related to sleep disturbances. Diabetes Care 2004; 27: 2464-2469.

26 Mallon L, Broman J-E, Hetta J. High incidence of diabetes in men with sleep complaints or short sleep duration: a 12-year followup study of a middle-aged population. Diabetes Care 2005; 28: 2762-2767.

27 Marshall NS, Glozier N, Grunstein RR. Is sleep duration related to obesity? A critical review of the epidemiological evidence. Sleep Med Rev 2008; 12: 289-298.

28 Taheri S, Thomas GN. Is sleep duration associated with obesitywhere do U stand? Sleep Med Rev 2008; 12: 299-302.

29 Marshall NS, Glozier N, Grunstein RR. Is sleep duration associated with obesity-U cannot be serious. Sleep Med Rev 2008; 12 : 303-305.

30 Bliwise DL, Young TB. The parable of parabola: what the Ushaped curve can and cannot tell us about sleep. Sleep 2007; 30: 1614-1615.

31 Patel SR, Hu FB. Short sleep duration and weight gain: a systematic review. Obesity 2008; 16: 643-653.

32 Cappuccio FP, Taggart FM, Kandala NB, et al. Meta-analysis of short sleep duration and obesity in children and adults. Sleep 2008; 31: 619-626.
33 Stranges S, Cappuccio FP, Kandala NB, et al. Cross-sectional versus prospective associations of sleep duration with changes in relative weight and body fat distribution: the Whitehall II Study. Am J Epidemiol 2008; 167: 321-329.

34 Horne J. Short sleep is a questionable risk factor for obesity and related disorders: statistical versus clinical significance. Biol Psychol 2008; 77: 266-276.

35 Horne J. Too weighty a link between short sleep and obesity? Sleep 2008; 31: 595-596.

36 Young T. Increasing sleep duration for a healthier (and less obese?) population tomorrow. Sleep 2008; 31: 593-594.

37 Vgontzas AN, Zoumakis E, Bixler EO, et al. Adverse effects of modest sleep restriction on sleepiness, performance, and inflammatory cytokines. J Clin Endocrinol Metab 2004; 89: 2119-2126.

38 Haack M, Sanchez E, Mullington JM. Elevated inflammatory markers in response to prolonged sleep restriction are associated with increased pain experience in healthy volunteers. Sleep 2007; 30: $1145-1152$.

39 Irwin MR, Wang M, Campomayor CO, et al. Sleep deprivation and activation of morning levels of cellular and genomic markers of inflammation. Arch Intern Med 2006; 166: 1756-1762.

40 Irwin MR, Wang M, Ribeiro D, et al. Sleep loss activates cellular inflammatory signaling. Biol Psychiatry 2008; 64: 538-540.

41 Bierhaus A, Wolf J, Andrassy M, et al. A mechanism converting psychosocial stress into mononuclear cell activation. Proc Natl Acad Sci USA 2003; 100: 1920-1925.

42 Irwin M, Thompson J, Miller C, et al. Effects of sleep and sleep deprivation on catecholamine and interleukin-2 levels in humans: clinical implications. J Clin Endocrinol Metab 1999; 84 1979-1985.

43 Irwin MR, Ziegler M. Sleep deprivation potentiates activation of cardiovascular and catecholamine responses in abstinent alcoholics. Hypertension 2005; 45: 252-257.

44 Knutson KL, Van Cauter E. Associations between sleep loss and increased risk of obesity and diabetes. Ann NY Acad Sci 2008, 1129: 287-304.

45 Taheri S, Zeitzer JM, Mignot E. The role of hypocretins (orexins) in sleep regulation and narcolepsy. Ann Rev Neurosci 2002; 25: 283-313.

46 Sakurai T. Roles of orexin/hypocretin in regulation of sleep/ wakefulness and energy homeostasis. Sleep Med Rev 2005; 9 ; 231-241.

47 Spiegel K, Knutson K, Leproult R, et al. Sleep loss: a novel risk factor for insulin resistance and type 2 diabetes. J Appl Physiol 2005; 99: 2008-2019.

48 American Diabetes Association, Diagnosis and classification of diabetes mellitus. Diabetes Care 2008; 31: Suppl. 1, S55-S60.

49 Grundy SM, Cleeman JI, Daniels SR, et al. Diagnosis and management of the metabolic syndrome: an American Heart Association/National Heart, Lung, and Blood Institute Scientific Statement. Circulation 2005; 112: 2735-2752.

50 World Health Organization. Definition, diagnosis, and classification of diabetes mellitus and its complications. Report of a WHO Consultation. Geneva, World Health Organization, 1999.

51 Grunstein RR, Stenlöf K, Hedner J, et al. Impact of obstructive sleep apnea and sleepiness on metabolic and cardiovascular risk factors in the Swedish Obese Subjects (SOS) Study. Int J Obes Relat Metab Disord 1995; 19: 410-418.

52 Elmasry A, Janson C, Lindberg E, et al. The role of habitual snoring and obesity in the development of diabetes: a 10-year follow-up study in a male population. J Intern Med 2000; 248: 13-20.

53 Elmasry A, Lindberg E, Berne C, et al. Sleep-disordered breathing and glucose metabolism in hypertensive men: a populationbased study. J Intern Med 2001; 249: 153-161.

54 Punjabi NM, Sorkin JD, Katzel LI, et al. Sleep disordered breathing and insulin resistance in middle-aged and overweight men. Am J Respir Crit Care Med 2002; 165: 677-682. 
55 Al-Delaimy WK, Manson JE, Willett WC, et al. Snoring as a risk factor for type II diabetes mellitus: a prospective study. Am J Epidemiol 2002; 155: 387-393.

56 Reichmuth KJ, Austin D, Skatrud JB, et al. Association of sleep apnea and type II diabetes: a population-based study. Am J Respir Crit Care Med 2005; 172: 1590-1595.

57 Shin C, Kim J, Kim J, et al. Association of habitual snoring with glucose and insulin metabolism in nonobese Korean adult men. Am J Respir Crit Care Med 2005; 171: 287-291.

58 Lam JCM, Lam B, Lam C-L, et al. Obstructive sleep apnea and the metabolic syndrome in community-based Chinese adults in Hong Kong. Respir Med 2006; 100: 980-987.

59 Joo SL, Choi HA, Kim J, et al. Habitual snoring is associated with elevated hemoglobin A1c levels in non-obese middle-aged adults. J Sleep Res 2006; 15: 437-444.

60 Onat A, Hergenç G, Uyarel H, et al. Obstructive sleep apnea syndrome is associated with metabolic syndrome rather than insulin resistance. Sleep Breath 2007; 11: 23-30.

61 Seicean S, Kirchner HL, Gottlieb DJ, et al. Sleep-disordered breathing and impaired glucose metabolism in normal-weight and overweight/obese individuals. Diabetes Care 2008; 31: 1001-1006.

62 Theorell-Haglow J, Berne C, Janson C, et al. Obstructive sleep apnoea is associated with decreased insulin sensitivity in females. Eur Respir J 2008; 31: 1054-1060.

63 Bjorkelund C, Bondyr-Carlsson D, Lapidus L, et al. Sleep disturbances in midlife unrelated to 32-year diabetes incidence: the prospective population study of women in Gothenburg. Diabetes Care 2005; 28: 2739-2744.

64 Stoohs RA, Facchini F, Guilleminault C. Insulin resistance and sleep-disordered breathing in healthy humans. Am J Respir Crit Care Med 1996; 154: 170-174.

65 Gruber A, Horwood F, Sithole J, et al. Obstructive sleep apnoea is independently associated with the metabolic syndrome but not insulin resistance state. Cardiovasc Diabetol 2006; 5: 22.

66 Katsumata K, Okada T, Miyao M, et al. High incidence of sleep apnea syndrome in a male diabetic population. Diabetes Res Clin Pract 1991; 13: 45-51.

67 Tiihonen M, Partinen M, Närvänen S. The severity of obstructive sleep apnoea is associated with insulin resistance. J Sleep Res 1993; 2: 56-61.

68 Strohl KP, Novak RD, Singer W, et al. Insulin levels, blood pressure and sleep apnea. Sleep 1994; 17: 614-618.

69 Vgontzas AN, Papanicolaou DA, Bixler EO, et al. Sleep apnea and daytime sleepiness and fatigue: relation to visceral obesity, insulin resistance, and hypercytokinemia. J Clin Endocrinol Metab 2000; 85: 1151-1158.

70 Ip MS, Lam B, Ng MM, et al. Obstructive sleep apnea is independently associated with insulin resistance. Am J Respir Crit Care Med 2002; 165: 670-676.

71 Meslier N, Gagnadoux F, Giraud P, et al. Impaired glucoseinsulin metabolism in males with obstructive sleep apnoea syndrome. Eur Respir J 2003; 22: 156-160.

72 Tassone F, Lanfranco F, Gianotti L, et al. Obstructive sleep apnoea syndrome impairs insulin sensitivity independently of anthropometric variables. Clin Endocrinol (Oxf) 2003; 59: 374-379.

73 Makino S, Handa H, Suzukawa K, et al. Obstructive sleep apnoea syndrome, plasma adiponectin levels, and insulin resistance. Clin Endocrinol 2006; 64: 12-19.

74 Peled N, Kassirer M, Shitrit D, et al. The association of OSA with insulin resistance, inflammation and metabolic syndrome. Respir Med 2007; 101: 1696-1701.

75 McArdle N, Hillman D, Beilin L, et al. Metabolic risk factors for vascular disease in obstructive sleep apnea: a matched controlled study. Am I Respir Crit Care Med 2007; 175: 190-195.

76 Kapsimalis F, Varouchakis G, Manousaki A, et al. Association of sleep apnea severity and obesity with insulin resistance,
C-reactive protein, and leptin levels in male patients with obstructive sleep apnea. Lung 2008; 186: 209-217.

77 Barcelo A, Barbe F, de la Pena M, et al. Insulin resistance and daytime sleepiness in patients with sleep apnea. Thorax 2008; 63 946-950.

78 Davies RJ, Turner R, Crosby J, et al. Plasma insulin and lipid levels in untreated obstructive sleep apnoea and snoring; their comparison with matched controls and response to treatment. J Sleep Res 1994; 3: 180-185.

79 Barceló A, Barbé F, Llompart E, et al. Effects of obesity on Creactive protein level and metabolic disturbances in male patients with obstructive sleep apnea. Am J Med 2004; 117: 118-121.

80 Sharma SK, Kumpawat S, Goel A, et al. Obesity, and not obstructive sleep apnea, is responsible for metabolic abnormalities in a cohort with sleep-disordered breathing. Sleep Med 2007 8: $12-17$.

81 Kahn R, Buse J, Ferrannini E, et al. The metabolic syndrome: time for a critical reappraisal. Diabetes Care 2005; 28: 2289-2304.

82 Kahn R. Metabolic syndrome: is it a syndrome? Does it matter? Circulation 2007; 115: 1806-1810.

83 Beaser RS, Levy P. Metabolic syndrome: a work in progress, but a useful construct. Circulation 2007; 115: 1812-1818.

84 Despres JP, Lemieux I. Abdominal obesity and metabolic syndrome. Nature 2006; 444: 881-887.

85 Alberti KG, Zimmet $P$, Shaw J. The metabolic syndrome-a new worldwide definition. Lancet 2005; 366: 1059-1062.

86 Opie LH. Metabolic syndrome. Circulation 2007; 115: e32-e35.

87 Despres J-P, Lemieux I, Bergeron J, et al. Abdominal obesity and the metabolic syndrome: contribution to global cardiometabolic risk. Arterioscler Thromb Vasc Biol 2008; 28: 1039-1049.

88 Sasanabe R, Banno K, Otake K, et al. Metabolic syndrome in Japanese patients with obstructive sleep apnea syndrome. Hypertens Res 2006; 29: 315-322.

89 Shiina K, Tomiyama H, Takata Y, et al. Concurrent presence of metabolic syndrome in obstructive sleep apnea syndrome exacerbates the cardiovascular risk: a sleep clinic cohort study. Hypertens Res 2006; 29: 433-441.

90 Kono M, Tatsumi K, Saibara T, et al. Obstructive sleep apnea syndrome is associated with some components of metabolic syndrome. Chest 2007; 131: 1387-1392.

91 Tkacova R, Dorkova Z, Molcanyiova A, et al. Cardiovascular risk and insulin resistance in patients with obstructive sleep apnea. Med Sci Monit 2008; 14: CR438-CR444.

92 Punjabi NM, Ahmed MM, Polotsky VY, et al. Sleep-disordered breathing, glucose intolerance, and insulin resistance. Respir Physiol Neurobiol 2003; 136: 167-178.

93 Vgontzas AN, Zoumakis E, Bixler EO, et al. Selective effects of CPAP on sleep apnoea-associated manifestations. Eur J Clin Invest 2008; 38: 585-595.

94 Vgontzas AN, Bixler EO, Chrousos GP. Sleep apnea is a manifestation of the metabolic syndrome. Sleep Med Rev 2005; 9: 211-224.

95 Saini J, Krieger J, Brandenberger G, et al. Continuous positive airway pressure treatment. Effects on growth hormone, insulin and glucose profiles in obstructive sleep apnea patients. Horm Metab Res 1993; 25: 375-381.

96 Brooks B, Cistulli PA, Borkman M, et al. Obstructive sleep apnea in obese noninsulin-dependent diabetic patients: effect of continuous positive airway pressure treatment on insulin responsiveness. I Clin Endocrinol Metab 1994; 79: $1681-1685$.

97 Cooper BG, White JE, Ashworth LA, et al. Hormonal and metabolic profiles in subjects with obstructive sleep apnea syndrome and the acute effects of nasal continuous positive airway pressure (CPAP) treatment. Sleep 1995; 18: 172-179. 
98 Saarelainen S, Lahtela J, Kallonen E. Effect of nasal CPAP treatment on insulin sensitivity and plasma leptin. J Sleep Res 1997; 6: 146-147.

99 Harsch IA, Schahin SP, Radespiel-Troger M, et al. Continuous positive airway pressure treatment rapidly improves insulin sensitivity in patients with obstructive sleep apnea syndrome. Am J Respir Crit Care Med 2004; 169: 156-162.

100 Hassaballa HA, Tulaimat A, Herdegen JJ, et al. The effect of continuous positive airway pressure on glucose control in diabetic patients with severe obstructive sleep apnea. Sleep Breath 2005; 9: 176-180.

101 Czupryniak L, Loba J, Pawlowski M, et al. Treatment with continuous positive airway pressure may affect blood glucose levels in nondiabetic patients with obstructive sleep apnea syndrome. Sleep 2005; 28: 601-603.

102 Babu AR, Herdegen J, Fogelfeld L, et al. Type 2 diabetes, glycemic control, and continuous positive airway pressure in obstructive sleep apnea. Arch Intern Med 2005; 165: 447-452.

103 Trenell MI, Ward JA, Yee BJ, et al. Influence of constant positive airway pressure therapy on lipid storage, muscle metabolism and insulin action in obese patients with severe obstructive sleep apnoea syndrome. Diabetes Obes Metab 2007; 9: 679-687.

104 Coughlin SR, Mawdsley L, Mugarza JA, et al. Cardiovascular and metabolic effects of CPAP in obese males with OSA. Eur Respir J 2007; 29: 720-727.

105 West SD, Nicoll DJ, Wallace TM, et al. Effect of CPAP on insulin resistance and $\mathrm{HbA1} \mathrm{c}$ in men with obstructive sleep apnoea and type 2 diabetes. Thorax 2007; 62: 969-974.

106 Dorkova Z, Petrasova D, Molcanyiova A, et al. Effects of CPAP on cardiovascular risk profile in patients with severe obstructive sleep apnea and metabolic syndrome. Chest 2008; 134: 686-692.

107 Pallayova M, Donic V, Tomori Z. Beneficial effects of severe sleep apnea therapy on nocturnal glucose control in persons with type 2 diabetes mellitus. Diab Res Clin Pract 2008; 81: e8-e11.

108 Schahin SP, Nechanitzki T, Dittel C, et al. Long-term improvement of insulin sensitivity during CPAP therapy in the obstructive sleep apnoea syndrome. Med Sci Monit 2008; 14: CR117-CR121.

109 Dawson A, Abel SL, Loving RT, et al. CPAP therapy of obstructive sleep apnea in type 2 diabetics improves glycemic control during sleep. J Clin Sleep Med 2008; 4: 538-542.

110 Grunstein RR, Stenlöf KS, Hedner JA, et al. Two year reduction in sleep apnea symptoms and associated diabetes incidence after weight loss in severe obesity. Sleep 2007; 30: 703-710.

111 Chin K, Shimizu K, Nakamura $\mathrm{T}$, et al. Changes in intraabdominal visceral fat and serum leptin levels in patients with obstructive sleep apnea syndrome following nasal continuous positive airway pressure therapy. Circulation 1999; 100: 706-712.

112 Harsch IA, Schahin SP, Bruckner K, et al. The effect of continuous positive airway pressure treatment on insulin sensitivity in patients with obstructive sleep apnoea syndrome and type 2 diabetes. Respiration 2004; 71: 252-259.

113 Harsch IA, Hahn EG, Pour Schahin S. Effect of CPAP on insulin resistance in patients with obstructive sleep apnoea and type 2 diabetes. Thorax 2008; 63: 384-385.

114 McNicholas WT. Cardiovascular outcomes of CPAP therapy in obstructive sleep apnea syndrome. Am J Physiol Regul Integr Comp Physiol 2007; 293: R1666-R1670.

115 Börgel J, Sanner BM, Bittlinsky A, et al. Obstructive sleep apnoea and its therapy influence high-density lipoprotein cholesterol serum levels. Eur Respir J 2006; 27: 121-127.

116 Steiropoulos P, Tsara V, Nena E, et al. Effect of continuous positive airway pressure treatment on serum cardiovascular risk factors in patients with obstructive sleep apnea-hypopnea syndrome. Chest 2007; 132: 843-851.
117 Lindberg E, Berne C, Elmasry A, et al. CPAP treatment of a population-based sample-what are the benefits and the treatment compliance? Sleep Med 2006; 7: 553-560.

118 Sandhu MS, Heald AH, Gibson JM, et al. Circulating concentrations of insulin-like growth factor-I and development of glucose intolerance: a prospective observational study. Lancet 2002; 359: 1740-1745.

119 Juul A, Scheike T, Davidsen M, et al. Low serum insulin-like growth factor I is associated with increased risk of ischemic heart disease: a population-based case-control study. Circulation 2002; 106: 939-944.

120 Aguilera CM, Gil-Campos M, Canete R, et al. Alterations in plasma and tissue lipids associated with obesity and metabolic syndrome. Clin Sci 2008; 114: 183-193.

121 Nagakawa $Y$, kishida $K$, Kihara S, et al. Nocturnal reduction in circulating adiponectin concentrations related to hypoxic stress in severe obstructive sleep apnea-hypopnea syndrome. Am J Physiol 2008; 294: E778-E784.

122 Zhang $\mathrm{XL}$, Yin $\mathrm{KS}$, Li C, et al. Effect of continuous positive airway pressure treatment on serum adiponectin level and mean arterial pressure in male patients with obstructive sleep apnea syndrome. Chin Med J 2007; 120: 1477-1481.

123 Masserini B, Morpurgo PS, Donadio F, et al. Reduced levels of adiponectin in sleep apnea syndrome. J Endocrinol Invest 2006; 29: 700-705.

124 Kohler M, Ayers L, Pepperell JC, et al. Effects of continuous positive airway pressure on systemic inflammation in patients with moderate to severe obstructive sleep apnoea: a randomised controlled trial. Thorax 2009; 64: 67-73.

125 Ogden CL, Carroll MD, Curtin LR, et al. Prevalence of overweight and obesity in the United States, 1999-2004. JAMA 2006; 295: 1549-1555.

126 Lobstein T, Jackson-Leach R. Child overweight and obesity in the USA: prevalence rates according to IOTF definitions. Int $J$ Pediatric Obes 2007; 2: 62-64.

127 Weiss R, Dziura J, Burgert TS, et al. Obesity and the metabolic syndrome in children and adolescents. N Engl J Med 2004; 350: 2362-2374.

128 Goodman E, Daniels SR, Meigs JB, et al. Instability in the diagnosis of metabolic syndrome in adolescents. Circulation 2007; 115: 2316-2322.

129 Dayyat E, Kheirandish-Gozal L, Gozal D. Childhood obstructive sleep apnea: one or two distinct entities? Sleep Med Clin 2007; 2: 433-444.

130 Verhulst SL, Rooman R, Van Gaal L, et al. Is sleep-disordered breathing an additional risk factor for the metabolic syndrome in obese children and adolescents? Int J Obes 2009; 33: 8-13.

131 Redline S, Storfer-Isser A, Rosen CL, et al. Association between metabolic syndrome and sleep-disordered breathing in adolescents. Am J Respir Crit Care Med 2007; 176: 401-408.

132 de la Eva RC, Baur LA, Donaghue KC, et al. Metabolic correlates with obstructive sleep apnea in obese subjects. J Pediatr 2002; 140: 654-659.

$133 \mathrm{Li} \mathrm{AM}$, Chan MH, Chan DF, et al. Insulin and obstructive sleep apnea in obese Chinese children. Pediatr Pulmonol 2006; 41: 11751181.

134 Tauman R, O'Brien LM, Ivanenko A, et al. Obesity rather than severity of sleep-disordered breathing as the major determinant of insulin resistance and altered lipidemia in snoring children. Pediatrics 2005; 116: e66-e73.

135 Waters KA, Sitha S, O'Brien LM, et al. Follow-up on metabolic markers in children treated for obstructive sleep apnea. Am J Respir Crit Care Med 2006; 174: 455-460.

136 Kaditis AG, Alexopoulos EI, Damani E, et al. Obstructive sleepdisordered breathing and fasting insulin levels in nonobese children. Pediatr Pulmonol 2005; 40: 515-523. 
137 Tauman R, Serpero LD, Capdevila OS, et al. Adipokines in children with sleep disordered breathing. Sleep 2007; 30: 443-449.

138 Gozal D, Capdevila OS, Kheirandish-Gozal L. Metabolic alterations and systemic inflammation in obstructive sleep apnea among nonobese and obese prepubertal children. Am J Respir Crit Care Med 2008; 177: 1142-1149.

139 Nakra N, Bhargava S, Dzuira J, et al. Sleep-disordered breathing in children with metabolic syndrome: the role of leptin and sympathetic nervous system activity and the effect of continuous positive airway pressure. Pediatrics. 2008; 122: e634-e642.

140 Apostolidou MT, Alexopoulos EI, Damani E, et al. Absence of blood pressure, metabolic, and inflammatory marker changes after adenotonsillectomy for sleep apnea in Greek children. Pediatr Pulmonol 2008; 43: 550-560.

141 Verhulst SL, Van Gaal L, De Backer W, et al. The prevalence, anatomical correlates and treatment of sleep-disordered breathing in obese children and adolescents. Sleep Med Rev 2008; 12: 339-346.

142 Kohler MJ, van den Heuvel CJ. Is there a clear link between overweight/obesity and sleep disordered breathing in children? Sleep Med Rev. 2008; 12: 347-361.

143 Spruyt K, Gozal D. Mr. Pickwick and his child went on a field trip and returned almost empty handed...What we do not know and imperatively need to learn about obesity and breathing during sleep in children!. Sleep Med Rev 2008; 12: 335-338.

144 Zhang Y, Proenca R, Maffei M, et al. Positional cloning of the mouse obese gene and its human homologue. Nature 1994; 372 425-432.

145 Trayhurn P, Beattie JH. Physiological role of adipose tissue: white adipose tissue as an endocrine and secretory organ. Proc Nutr Soc 2001; 60: 329-339.

146 Yamauchi $\mathrm{T}$, Kamon J, Waki H, et al. The fat-derived hormone adiponectin reverses insulin resistance associated with both lipoatrophy and obesity. Nat Med 2001; 7: 941-946.

147 Yamauchi $\mathrm{T}$, Kamon J, Ito $\mathrm{Y}$, et al. Cloning of adiponectin receptors that mediate antidiabetic metabolic effects. Nature 2003; 423: 762-769.

148 Ip MS, Lam KS, Ho C, et al. Serum leptin and vascular risk factors in obstructive sleep apnea. Chest 2000; 118: 580-586.

149 Ozturk L, Unal M, Tamer L, et al. The association of the severity of obstructive sleep apnea with plasma leptin levels. Arch Otolaryngol Head Neck Surg 2003; 129: 538-540.

150 Phillips BG, Kato M, Narkiewicz K, et al. Increases in leptin levels, sympathetic drive, and weight gain in obstructive sleep apnea. Am J Physiol Heart Circ Physiol 2000; 279: H234-H237.

151 Ulukavak Ciftci T, Kokturk O, Bukan N, et al. Leptin and ghrelin levels in patients with obstructive sleep apnea syndrome. Respiration 2005; 72: 395-401.

152 Kapsimalis F, Varouchakis G, Manousaki A, et al. Association of sleep apnea severity and obesity with insulin resistance, Creactive protein, and leptin levels in male patients with obstructive sleep apnea. Lung 2008; 186: 209-217.

153 Sanner BM, Kollhosser $\mathrm{P}$, Buechner $\mathrm{N}$, et al. Influence of treatment on leptin levels in patients with obstructive sleep apnoea. Eur Respir J 2004; 23: 601-604.

154 Harsch IA, Konturek PC, Koebnick C, et al. Leptin and ghrelin levels in patients with obstructive sleep apnoea: effect of CPAP treatment. Eur Respir J 2003; 22: 251-257.

155 Ambrosini G, Nath AK, Sierra-Honigmann MR, et al. Transcriptional activation of the human leptin gene in response to hypoxia. Involvement of hypoxia-inducible factor 1 . J Biol Chem 2002; 277: 34601-34609.

$156 \mathrm{Xu} \mathrm{H}$, Barnes GT, Yang Q, et al. Chronic inflammation in fat plays a crucial role in the development of obesity-related insulin resistance. J Clin Invest 2003; 112: 1821-1830.

157 Trayhurn P, Wood IS. Adipokines: inflammation and the pleiotropic role of white adipose tissue. Br J Nutr 2004; 92 347-355.
158 Hosogai N, Fukuhara A, Oshima K, et al. Adipose tissue hypoxia in obesity and its impact on adipocytokine dysregulation. Diabetes 2007; 56: 901-911.

159 Wenger $\mathrm{RH}$. Cellular adaptation to hypoxia: $\mathrm{O}_{2}$-sensing protein hydroxylases, hypoxia-inducible transcription factors, and $\mathrm{O}_{2^{-}}$ regulated gene expression. Faseb J 2002; 16: 1151-1162.

160 Garvey JF, Taylor CT, McNicholas WT. Cardiovascular disease in obstructive sleep apnoea syndrome: the role of intermittent hypoxia and inflammation. Eur Respir J 2009; 33: 1195-1205.

161 Charo IF, Taubman MB. Chemokines in the pathogenesis of vascular disease. Circ Res 2004; 95: 858-866.

162 Sell H, Eckel J. Monocyte chemotactic protein-1 and its role in insulin resistance. Curr Opin Lipidol 2007; 18: 258-262.

163 Shoelson SE, Lee J, Yuan M. Inflammation and the IKK $\beta /$ ІкB/ $\mathrm{NF}-\kappa \mathrm{B}$ axis in obesity- and diet-induced insulin resistance. Int $J$ Obes Relat Metab Disord 2003; 27: Suppl. 3, S49-S52.

164 Cai D, Yuan M, Frantz DF, et al. Local and systemic insulin resistance resulting from hepatic activation of IKK- $\beta$ and NF- $\kappa B$. Nat Med 2005; 11: 183-190.

165 Lavie L. Obstructive sleep apnoea syndrome-an oxidative stress disorder. Sleep Med Rev 2003; 7: 35-51.

166 Ryan S, Taylor CT, McNicholas WT. Selective activation of inflammatory pathways by intermittent hypoxia in obstructive sleep apnea syndrome. Circulation 2005; 112: 2660-2667.

167 Ryan S, Taylor CT, McNicholas WT. Predictors of elevated nuclear factor- $\kappa \mathrm{B}$-dependent genes in obstructive sleep apnea syndrome. Am J Respir Crit Care Med 2006; 174: 824-830.

168 Minoguchi K, Yokoe T, Tazaki T, et al. Increased carotid intimamedia thickness and serum inflammatory markers in obstructive sleep apnea. Am J Respir Crit Care Med 2005; 172: 625-630.

169 Baguet JP, Hammer L, Levy P, et al. The severity of oxygen desaturation is predictive of carotid wall thickening and plaque occurrence. Chest 2005; 128: 3407-3412.

170 Drager LF, Bortolotto LA, Lorenzi MC, et al. Early signs of atherosclerosis in obstructive sleep apnea. Am J Respir Crit Care Med 2005; 172: 613-618.

171 Drager LF, Bortolotto LA, Figueiredo AC, et al. Effects of continuous positive airway pressure on early signs of atherosclerosis in obstructive sleep apnea. Am J Respir Crit Care Med 2007; 176: 706-712.

172 Lorenzi-Filho G, Drager LF. Obstructive sleep apnea and atherosclerosis: a new paradigm. Am J Respir Crit Care Med 2007; 175: 1219-1221.

173 Guilleminault C, Kirisoglu C, Ohayon MM. C-reactive protein and sleep-disordered breathing. Sleep 2004; 27: 1507-1511.

174 Taheri S, Austin D, Lin L, et al. Correlates of serum C-reactive protein (CRP)-no association with sleep duration or sleep disordered breathing. Sleep 2007; 30: 991-996.

175 Ryan S, Nolan GM, Hannigan E, et al. Cardiovascular risk markers in obstructive sleep apnoea syndrome and correlation with obesity. Thorax 2007; 62: 509-514.

176 Alam I, Lewis K, Stephens JW, et al. Obesity, metabolic syndrome and sleep apnoea: all pro-inflammatory states. Obes Rev 2007; 8: 119-127.

177 Thalmann S, Meier CA. Local adipose tissue depots as cardiovascular risk factors. Cardiovasc Res 2007; 75: 690-701.

178 Levy P, Pepin JL, Arnaud C, et al. Intermittent hypoxia and sleep-disordered breathing: current concepts and perspectives. Eur Respir J 2008; 32: 1082-1095.

179 Li J, Thorne LN, Punjabi NM, et al. Intermittent hypoxia induces hyperlipidemia in lean mice. Circ Res 2005; 97: 698-706.

180 Dematteis M, Julien C, Guillermet C, et al. Intermittent hypoxia induces early functional cardiovascular remodeling in mice. $A m$ J Respir Crit Care Med 2008; 177: 227-235. 
181 Volgin DV, Kubin L. Chronic intermittent hypoxia alters hypothalamic transcription of genes involved in metabolic regulation. Auton Neurosci 2006; 126-127: 93-99.

182 Jun J, Polotsky VY. Sleep disordered breathing and metabolic effects: evidence from animal models. Sleep Med Clin 2007; 2: 263-277.

183 Savransky V, Nanayakkara A, Li J, et al. Chronic intermittent hypoxia induces atherosclerosis. Am J Respir Crit Care Med 2007; 175: $1290-1297$.

184 Li J, Savransky V, Nanayakkara A, et al. Hyperlipidemia and lipid peroxidation are dependent on the severity of chronic intermittent hypoxia. J Appl Physiol 2007; 102: 557-563.

185 Iiyori N, Alonso LC, Li J, et al. Intermittent hypoxia causes insulin resistance in lean mice independent of autonomic activity. Am J Respir Crit Care Med 2007; 175: 851-857.

186 Li J, Bosch-Marce M, Nanayakkara A, et al. Altered metabolic responses to intermittent hypoxia in mice with partial deficiency of hypoxia-inducible factor- $1 \alpha$. Physiol Genomics 2006; 25: 450-457.

187 Yokoe T, Alonso LC, Romano LC, et al. Intermittent hypoxia reverses the diurnal glucose rhythm and causes pancreatic betacell replication in mice. J Physiol 2008; 586: 899-911.
188 Li J, Grigoryev DN, Ye SQ, et al. Chronic intermittent hypoxia upregulates genes of lipid biosynthesis in obese mice. J Appl Physiol 2005; 99: 1643-1648.

189 Polotsky VY, Li J, Punjabi NM, et al. Intermittent hypoxia increases insulin resistance in genetically obese mice. J Physiol 2003; 552: 253-264.

190 Day CP, James OF. Steatohepatitis: a tale of two "hits"? Gastroenterology 1998; 114: 842-845.

191 Savransky V, Bevans S, Nanayakkara A, et al. Chronic intermittent hypoxia causes hepatitis in a mouse model of dietinduced fatty liver. Am J Physiol Gastrointest Liver Physiol 2007; 293: G871-G877.

192 Savransky V, Nanayakkara A, Vivero A, et al. Chronic intermittent hypoxia predisposes to liver injury. Hepatology 2007; 45: 1007-1013.

193 Savransky V, Jun J, Li J, et al. Dyslipidemia and atherosclerosis induced by chronic intermittent hypoxia are attenuated by deficiency of stearoyl coenzyme A desaturase. Circ Res 2008; 103: $1173-1180$.

194 Verhulst SL, Jacobs S, Aerts L, et al. Sleep-disordered breathing: a new risk factor of suspected fatty liver disease in overweight children and adolescents? Sleep Breath 2009; 13: 207-210. 